\title{
The Insecticidal Proteins of Bacillus thuringiensis
}

\author{
P. ANanda Kumar, ${ }^{\star}$ R. P. Sharma, ${ }^{\star}$ AND V. S. MaliK ${ }^{\dagger}$ \\ ${ }^{*}$ National Research Centre for Plant Biotechnology \\ Indian Agricultural Research Institute \\ New Delhi 110012, India \\ + U.S. Department of Agriculture \\ Riverdale, Maryland 20737
}

\footnotetext{
I. Introduction

II. Classification of Bt Toxins

III. Structure of Bt Toxin Proteins and Genes

IV. Screening for New Bt Toxin Proteins and Genes

V. Mechanism of Action

VI. Bt as a Biological Insecticide

A. Construction of Novel Bt Strains by Conjugation

B. Construction of Recombinant Bt Strains

C. Construction of Transgenic Microbes

D. Baculoviruses as Bt Vectors

E. Insect-Tolerant Transgenic Crop Plants

VII. Resistance Development and Management Strategies
A. Rotations
B. Mixtures of Toxins
C. Refuges
D. Toxin Doses
E. Gene Expression

VIII. Epilogue

References
}

\section{Introduction}

Bacillus thuringiensis $(\mathrm{Bt})$ is a gram-positive, aerobic, endospore-forming bacterium belonging to morphological group I along with Bacillus cereus, Bacillus anthracis, and Bacillus laterosporus (Parry et al., 1983). All these bacteria have endospores. Bt, however, is recognized by its parasporal body (known as the crystal) that is proteinaceous in nature and possesses insecticidal properties. These insecticidal proteins, synthesized during sporulation, are tightly packed by hydrophobic bonds and disulfide bridges. Various forms of true crystals have been observed using phase contrast microscope (Srinivas et al., 1995; Jung et al., 1995). The most common shape is a bipyramidal structure (Fig. 1). A Bt mutant defective in sporulation accumulates insecticidal proteins to form large crystal inclusion (Fig. 2) that remained encapsulated within the ghost 


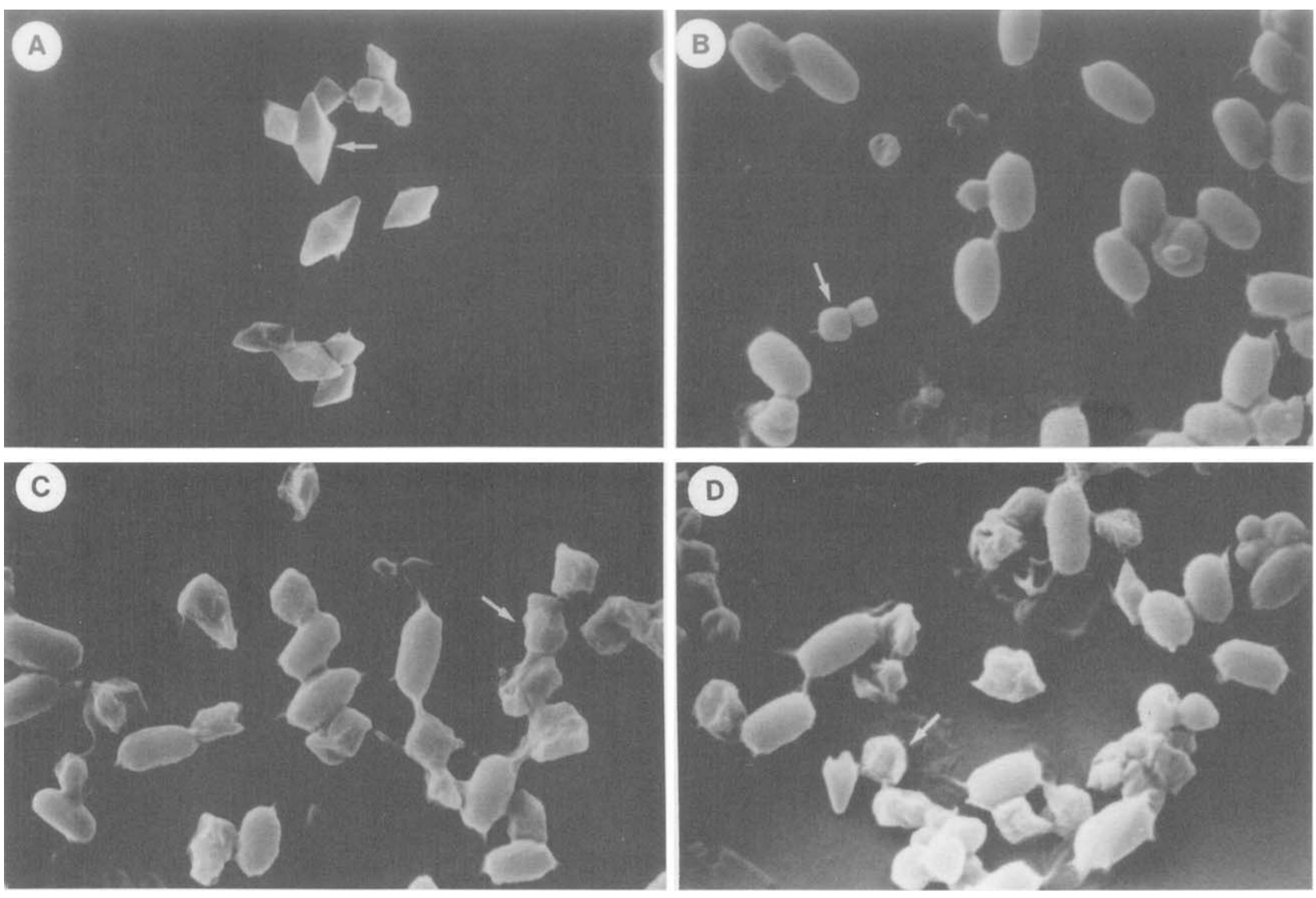

Fig. 1. Scanning electron micrograph of Bacillus thuringiensis crystals: (A) bipyramidal crystals produced by a lepidopteranactive strain; (B) spherical crystals produced by a mosquito-active strain; ( $C$ and D) irregularly shaped crystals produced by nontoxic strains (arrows indicate crystals). Reproduced with permission from Chilcote, C.N. and Wigley P.J. (1994). Agric. Eco systems Environ. 49, 51-57. 


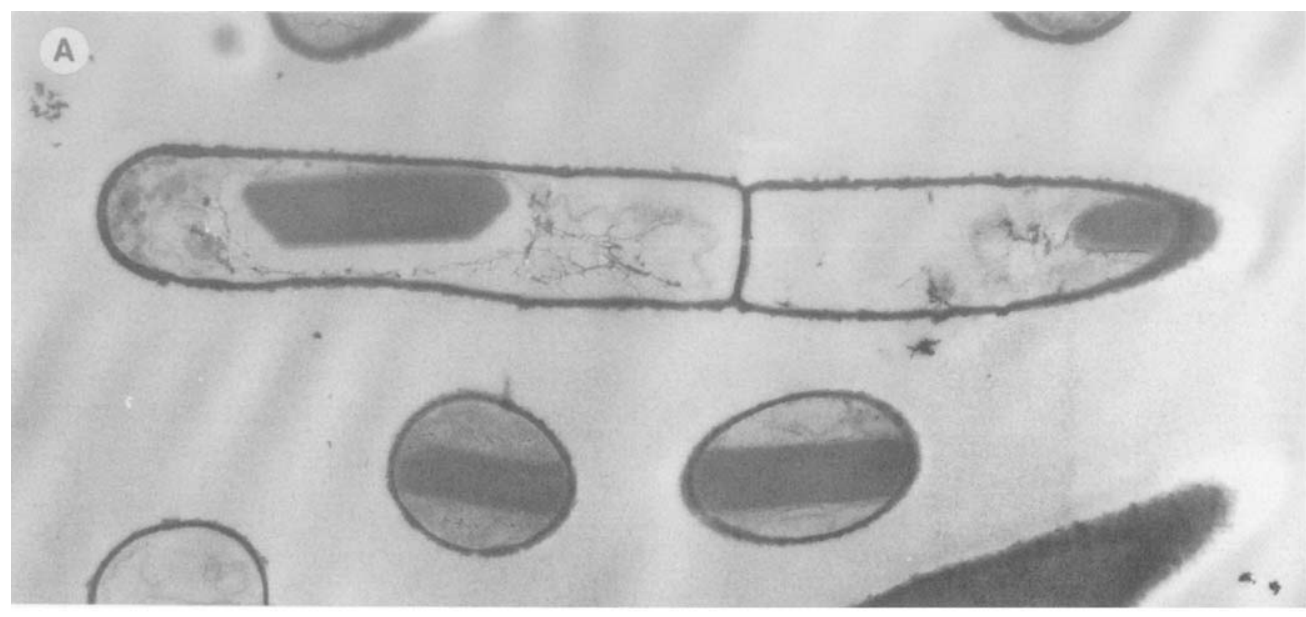

B

FIG. 2. Electron micrographs of a SpoOA mutant strain overproducing the CryIIIA crystal protein. Reproduced with permission from D. Lereclus, Institut Pasteur, Paris. 
cell (Lereclus et al., 1915). The first record on Bt goes back to 1901, when Ishiwata discovered a bacterium from diseased silkworm larvae that he named Bacillus sotto (Ishiwata, 1901). Between 1909 and 1912, Berliner (1915), working at a research station for grain processing in Berlin, investigated an infectious disease of the Mediterranean flour moth (Ephestia kuehniella). The infected insects were originally obtained from a mill in the district of Thueringen. In a detailed report, Berliner (1915) described a spore-forming bacterium as the causative agent and designated it as $B$. thuringiensis.

The first practical application of Bt was reported by Husz (1928) who isolated a Bt strain from Ephestia and tested it on European corn borer. This work eventually led to the first commercial product, Sporeine, which was produced in France in 1938 (Luthy et al., 1982). The development of potent organic insecticides, however, prevented the interest for biological alternatives for pest control to some extent. The pioneering research of Steinhaus (1951) on Bt and a growing realization that organic insecticides are deleterious to the environment and human health spurred a renewed interest in Bt in the 1960s. This led to the introduction of viable Bt biopesticides like Thuricide and Dipel. For many years, the inclusion body protein and spores were generally recognized as the two essential ingredients for most of the insecticidal activity of $B$. thuringiensis. Scientists at the Sandoz company and Asano and Hori (1995) discovered in the supernatant of the $B$. thuringiensis a growth medium potency-enhancing factor, Kurstakolin (Fig. 3), which enhances the insecticidal activity of $B$. thuringiensis cellular preparations by $30 \%$.

There are many subspecies and serotypes of Bt with a range of wellcharacterized insecticidal proteins or Bt toxins. Known Bt toxins kill subsets of insects among the Lepidoptera, Coleoptera, Diptera (Hofte and Whiteley, 1989), and nematodes (Feitelson et al., 1992). The host range of Bt has expanded considerably in recent years due to extensive<smiles>NC(=O)NCC(NC(=O)[C@@H](O)[C@H](O)[C@H](N)C(O)CC(O)C(N)CO)C(N)=O</smiles>

\section{$\mathrm{C}_{13} \mathrm{H}_{28} \mathrm{~N}_{6} \mathrm{O}_{8}$}

FIG. 3. Structure of Kurstakolin. 
screening programs (Table I). By virtue of the lack of toxicity toward other species of animals, human beings, and plants, there is tremendous potential for exploiting $\mathrm{Bt}$ as a biological control agent ( Jones and Khachatourians, 1995; Salama et al., 1995; Bradley et al., 1995).

Various aspects of Bt fermentation (Capalbo, 1995; Gangurde and Shethna, 1995), biology and genetics (Bulla et al., 1978; Aronson, 1986), molecular biology (Hofte and Whiteley, 1989; Yoshisue et al., 1995a; Dervyn et al., 1995), mechanism of action (Gill et al., 1992; Knowles, 1994), application as biopesticide (Gawron-Burke and Baum, 1991;

TABLE I

HOST RANGE OF Bacillus thuringiensis

\begin{tabular}{|c|c|c|c|}
\hline \multirow[b]{2}{*}{ Order } & \multirow[b]{2}{*}{ Toxin } & \multicolumn{2}{|c|}{ Susceptible families } \\
\hline & & Family & Example \\
\hline \multicolumn{4}{|l|}{ Insecta } \\
\hline \multirow[t]{6}{*}{ Lepidoptera } & \multirow[t]{6}{*}{$\delta$-Endotoxin } & \multicolumn{2}{|c|}{ Most lepidopteran families susceptible examples } \\
\hline & & Spingidae & Hawkmoths \\
\hline & & Pieridae & Cabbage worms \\
\hline & & Lymantriidae & Tussock moths \\
\hline & & Tortricidae & Leafroller moths \\
\hline & & Noctuidae & Cutworms/armyworms \\
\hline \multirow[t]{9}{*}{ Diptera } & \multirow[t]{7}{*}{ 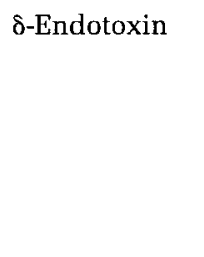 } & Culicidae & Mosquitoes \\
\hline & & Simuliidae & Blackflies \\
\hline & & Anisopodidae & Gnats \\
\hline & & Chironomidae & Midges \\
\hline & & Psychodiae & Moth flies \\
\hline & & Sciaridae & Black fungus gnats \\
\hline & & Tipulidae & Craneflies \\
\hline & \multirow[t]{2}{*}{ Thiringiensin } & Muscidae & Houseflies \\
\hline & & Calliphoridae & Blowflies \\
\hline Coleoptera & \multirow[t]{3}{*}{$\delta$-Endotoxin } & Chrysomelidae & Leaf beetles \\
\hline \multirow[t]{2}{*}{ Phthiraptera } & & Philopteridae & Bird lice \\
\hline & & Trichodectidae & Mammalian lice \\
\hline \multicolumn{4}{|l|}{ Arachnida } \\
\hline \multirow[t]{2}{*}{ Acari } & \multirow[t]{2}{*}{ Thuringiensin } & Dermanyssidae & Animal mites \\
\hline & & Tetranychidae & Phytophagous mites \\
\hline \multicolumn{4}{|l|}{ Nematoda } \\
\hline Strongylida & $?$ & Trichostrongylidae & $\begin{array}{l}\text { Animal endoparasitic } \\
\text { nematodes }\end{array}$ \\
\hline Tylenchida & $?$ & Tylenchidae & $\begin{array}{l}\text { Phytophagous nema- } \\
\text { todes }\end{array}$ \\
\hline
\end{tabular}


Aronson, 1994, Pedersen et al., 1995; Farrar and Ridgway, 1995; Yang et al., 1995; Gibson et al., 1995; Li et al., 1995), and Bt transgenic plants (Peferoen, 1992; Kumar and Sharma, 1994) have been reviewed. Here, the classification and mode of action of Bt toxins are discussed. Strategies to screen new Bt strains/genes, expression of the toxin protein in transgenic microorganisms (Shin et al., 1995), and plants and various resistance management strategies in agricultural systems are examined. The review puts emphasis on agricultural application of Bt.

\section{Classification of Bt Toxins}

A large number of $\mathrm{Bt}$ isolates are now available in laboratories around the world (Schnepf, 1995; Jung et al., 1995; Burtseva et al., 1995; Shin et al., 1995). New strains are being added every year. Bt strains can be characterized by a number of techniques including serotyping, crystal serology, crystal morphology, protein profiles, peptide mapping, DNA probes, and insecticidal activity. De Barjac first attempted to classify Bt toxins based on flagellar $(\mathrm{H})$ agglutination (De Barjac and Bonnefoi, 1962). Recently, the classification of $B t$ based on $H$ antigen was revised (De Barjac and Franchon, 1990) (Table II). More than $40 \mathrm{H}$-serotypes are

TABLE II

ClasSIFICATION OF Bacillus thuringiensis

\begin{tabular}{lll}
\hline H-antigen & \multicolumn{1}{c}{ Variety } & Toxicity $^{a}$ \\
\hline 1 & thuringiensis & L,D \\
2 & finitimus & \\
3a,3c & alesti & $\mathrm{L}$ \\
3a,3b,3c & kurstaki & $\mathrm{L}, \mathrm{D}$ \\
3a,3d & sumiyoshiensis & \\
3a,3d,3e & fukuokaensis & $\mathrm{D}$ \\
$4 \mathrm{a}, 4 \mathrm{~b}$ & sotto & $\mathrm{L}$ \\
$4 \mathrm{a}, 4 \mathrm{c}$ & kenyae & $\mathrm{L}, \mathrm{D}$ \\
$5 \mathrm{a}, 5 \mathrm{~b}$ & galleriae & $\mathrm{L}, \mathrm{C}$ \\
$5 \mathrm{a}, 5 \mathrm{c}$ & canadensis & $\mathrm{L}$ \\
6 & entomocidus & $\mathrm{L}$ \\
$6 \mathrm{a}, 6 \mathrm{c}$ & oyamensis & \\
7 & aizawai & $\mathrm{L}, \mathrm{D}$ \\
$8 \mathrm{a}, 8 \mathrm{~b}$ & morrisoni & $\mathrm{L}, \mathrm{D}, \mathrm{C}$ \\
$8 \mathrm{a}, 8 \mathrm{c}$ & ostriniae & $\mathrm{L}$ \\
$8 \mathrm{~b}, 8 \mathrm{~d}$ & nigeriensis & \\
\hline
\end{tabular}

(continues) 
TABLE II-Continued

\begin{tabular}{|c|c|c|}
\hline H-antigen & Variety & Toxicity ${ }^{a}$ \\
\hline 9 & tolworthi & \\
\hline $\mathrm{L}, \mathrm{D} 10 \mathrm{a}, 10 \mathrm{~b}$ & darmstadiensis & L,D \\
\hline $\begin{array}{l}10 \mathrm{a}, 10 \mathrm{c} \\
\text { toumanoffi }\end{array}$ & londrina $11 \mathrm{a}, 11 \mathrm{~b}$ & \\
\hline $11 \mathrm{a}, 11 \mathrm{c}$ & kyushuensis & L,D \\
\hline 12 & $\begin{array}{l}\text { thompsoni } \\
\text { pakistani }\end{array}$ & $\mathrm{L}, \mathrm{D} 13$ \\
\hline 14 & israelensis & $\mathrm{D}$ \\
\hline 15 & dakota & \\
\hline 16 & indiana & \\
\hline 17 & tohokuensis & \\
\hline $18 a, 18 b$ & kumamotoensis & $\mathrm{C}$ \\
\hline $18 \mathrm{a}, 18 \mathrm{c}$ & yosoo & \\
\hline 19 & tochigiensis & \\
\hline $20 a, 20 b$ & yunnanensis & $\mathrm{L}$ \\
\hline $20 \mathrm{a}, 20 \mathrm{c}$ & pondicheriensis & $\mathrm{L}$ \\
\hline 21 & colmeri & \\
\hline 22 & shandongiensis & $L$ \\
\hline 23 & japonensis & $\mathrm{C}$ \\
\hline $24 a, 24 b$ & neoleonensis & \\
\hline $24 a, 24 c$ & novosibirsk & \\
\hline 25 & coreanensis & \\
\hline 26 & silo & \\
\hline 27 & mexicanensis & $\mathrm{L}$ \\
\hline $28 a, 28 b$ & monterrey & \\
\hline $28 a, 28 c$ & jegathesan & $\mathrm{D}$ \\
\hline 29 & amagiensis & \\
\hline 30 & medellin & $\mathrm{D}$ \\
\hline 31 & toguchini & \\
\hline 32 & cameroun & \\
\hline 33 & leesis & \\
\hline 34 & konkukian & \\
\hline 35 & seoulensis & \\
\hline 36 & malaysiensis & $\mathrm{D}$ \\
\hline 37 & andalousiensis & \\
\hline 38 & oswaldocruzi & \\
\hline 39 & brasiliensis & \\
\hline 40 & huazhongensis & \\
\hline 41 & sooncheon & \\
\hline 42 & jinghongiensis & \\
\hline 43 & guiyangiensis & \\
\hline 44 & higo & \\
\hline 45 & roskildiensis & \\
\hline
\end{tabular}

${ }^{a} L$, lepidopteran active; $D$, dipteran active; $C$, coleopteran active. 
now available and in many of these the array of Bt toxin genes present in isolates from a particular serovar are the same (Rabinovitch et al., 1995). A notable exception is the presence of very different Bt toxin genes in subspecies morrisoni and tenebrionis within serotype $8 \mathrm{a}, \mathrm{b}$. Some of the serotypes are divided into subserotypes that can be differentiated by PCR (Bourque et al., 1993; Brousseau et al., 1993). However, a high level of sequence similarity among $B$. anthransis, B. cereus, and $B$. Thuringiensis does not permit construction of sequence-specific probes to be used in identification (Bourque et al., 1994).

The most useful scheme for classification of Bt toxins is based primarily on homology of toxin gene sequences and the spectrum of insecticidal activity (Hofte and Whiteley, 1989; Ogiwara et al., 1995). A large number of distinct $\mathrm{Bt}$ toxin genes have been cloned and sequenced since the first report published in 1981 (Schnepf and Whiteley, 1981). Hofte and Whiteley (1989) have classified 42 Bt genes into 14 distinct types and grouped them into four major classes. The classes are cryI (Lepidoptera specific), cryII (Lepidoptera and Diptera specific), cryIII (Coleoptera specific), and cryIV (Diptera specific). Many more Bt genes have since been sequenced and analyzed. Following the analysis of toxin domains of 29 distinct Bt toxin proteins, Feitelson et al. (1992) added two new major classes, $c r y V$ and $c r y V I$. Several novel genes were also added within the previously defined classes (Table III). The nomenclature of Hofte and Whiteley (1989), based mainly on insecticidal activity, failed to accommodate genes that were highly homologous to known genes but with a different insecticidal spectrum. CryIIA and $I B$ were included in the Diptera-specific class because it is known that cryIIB is inactive against Diptera. cryIC is toxic to both Diptera and Lepidoptera (Smith and Ellar, 1994). Several genes with differing homology and bioactivity were named $c r y V$, the next available Roman number in the original system (Gleave et al., 1992, Tailor et al., 1992).

Based on amino acid identity of full-length gene products, Crickmore et al. (1996) have introduced a systematic nomenclature for classifying the cry genes and their protein products. Most cry genes retain the name assigned by Hofte and Whiteley with a substitution of Arabic for Roman numerals (e.g., cryl $A a$ ) to accommodate the newly discovered genes. Fifty genes comprising 16 homology groups are systematically arranged. Their dendrogram depicts the possible evolutionary relationships between the entire set of Bt toxins. Primary through quaternary ranks are based on 45, 75 , and $95 \%$ level of sequence identity. Eighteen sets at the primary rank, CytA, CytB, and Cry1 through -16, are defined into 4 homology groups. Cry1, $-3,-4,-7,-8,-9$ and -10 form the largest group. Cry2 and Cry11 are the second group. The third group is Cry5, $-12,-13$ and -14 . The fourth group is the two Cyt proteins. The Cry6, -15 , and -16 consist of unique proteins. 
TABLE III

Bacillus thuringiensis Crystal Protein Genes

\begin{tabular}{lcc}
\hline Gene designation & Predicted $M_{\mathrm{r}}$ & Toxicity \\
\hline cryIA $(a),(b),(c)$ & $131-133$ & $\mathrm{~L}$ \\
$I B$ & 137 & $\mathrm{~L}$ \\
$I C$ & 134 & $\mathrm{~L}$ \\
$I D$ & 133 & $\mathrm{~L}$ \\
$I E$ & 137 & $\mathrm{~L}$ \\
$I F$ & 134 & $\mathrm{~L}$ \\
$I G$ & 130 & $\mathrm{~L}$ \\
cryIIA & 71 & $\mathrm{~L}, \mathrm{D}$ \\
IIB & 71 & $\mathrm{~L}$ \\
$I I C$ & 71 & $\mathrm{~L}$ \\
cryIIIA & 73 & $\mathrm{C}$ \\
IIIB & 73 & $\mathrm{C}$ \\
IIIC(a),(b) & 73 & $\mathrm{C}$ \\
cryIVA & 134 & $\mathrm{D}$ \\
IVB & 128 & $\mathrm{D}$ \\
$I V C$ & 77 & $\mathrm{D}$ \\
$I V D$ & 72 & $\mathrm{D}$ \\
cryV & 80 & $\mathrm{~L}, \mathrm{C}$ \\
Genes not yet cloned & 130 & $?$ \\
& 100 & $?$ \\
& 40 & $?$ \\
\hline
\end{tabular}

${ }^{a}$ L, Lepidoptera; D, Diptera; C, Coleoptera; Based on Hofte and Whiteley (1989).

Crickmore et al. (1996) define cry as a gene from $B$. thuringiensis encoding a parasporal inclusion protein that exhibits pesticide activity or is homologous to a known cry gene.

1. The mnemonic cry shall remain for the crystal-forming pesticidal genes from B. thuringiensis. The cry gene nomenclature shall be distinguished at all ranks on the basis of comparative amino acid sequence identity of the full-length gene products.

2. The primary rank of the nomenclature shall be Arabic numbers. The cry genes whose products share less than $45 \%$ amino acid homology shall be characterized by different Arabic numbers.

3. The secondary rank shall be an uppercase letter. The cry genes of the same rank whose products show less than $75 \%$ homology shall be separated into different secondary ranks.

4. The tertiary rank shall be a lowercase letter without parentheses. The cry genes whose products share less than $95 \%$ homology shall be given different tertiary ranks. 
5. The quaternary rank shall be allele numbers. The cry genes whose products differ in amino acid sequence, but are more than $95 \%$ identical to each other, shall be given separate quaternary ranks.

Crickmore et al. (1996) are the $B$. thuringiensis cry Gene Nomenclature Committee, a standing committee of the Bacillus Genetic Stock Center. They will assist workers in the field of $B$. thuringiensis genetics in assigning names of new cry genes and periodically review the literature of the cry genes.

\section{Structure of Bt Toxin Proteins and Genes}

Bt toxin genes are usually plasmid borne (Gonzalez et al., 1995) but also chromosomally located (Carlson and Kolsto, 1993; Klier et al., 1982; Kronstad et al., 1983). The Bt toxin genes are encoded on plasmids of molecular weight 40-150 mDa (Carlton and Gonzalez, 1985; Jensen et al., 1995). Most of the plasmids are of low copy number. In addition to the toxin-encoding plasmids, there are often several other cryptic plasmids of 4-150 mDa whose function is not clearly known. Many of the plasmid-encoded toxin genes are bordered by transposons and/or insertion sequences (Delecluse et al., 1990). Dervyn et al. (1995) examined the transcriptional regulation of the $c r y I V D$ gene operon from $B$. thuringiensis subspecies israelensis.

Hofte and Whiteley (1989) compared sequences among a number of toxins with varying specificities and found five well-conserved regions designated blocks 1-5 (Fig. 4). Exceptions to this include CryIVC toxin of Bt subspecies israelensis and a novel toxin from subspecies thompsoni (Brown and Whiteley, 1992). Blocks 1 and 2 are very hydrophobic and are present as amphipathic $\alpha$-helices with membranespanning potential. The protoxins designated CryIA-CryIG, CryIVA, and CryIVB contain 1100-1200 amino acids and the toxin is processed from within the amino half as shown in Fig. 4. The CryII, CryIII, and CryIVD protoxins are smaller, with processing to toxins as indicated. The carboxyl halves of the CryI, CryIVA, and CryIVB protoxins are also highly conserved except that there is a deletion of 26 amino acids in CryIA(b) protoxins.

On the basis of the conservation of the defined blocks, it was postulated that all of the Bt toxins probably have a three-dimensional conformation similar to that of a CryIIIA toxin reported by Li et al. (1991) (Fig. 5). According to this, the first 285 residues are present as a bundle of seven amphipathic $\alpha$-helices, wherein six are arranged in a circle, and helix 5 is in the center (domain I). Residues 286-500 are organized as three $\beta$-sheets (domain II) and contribute to the toxin specificity. The remaining amino acids are also present as $\beta$-sheets and arranged like a 


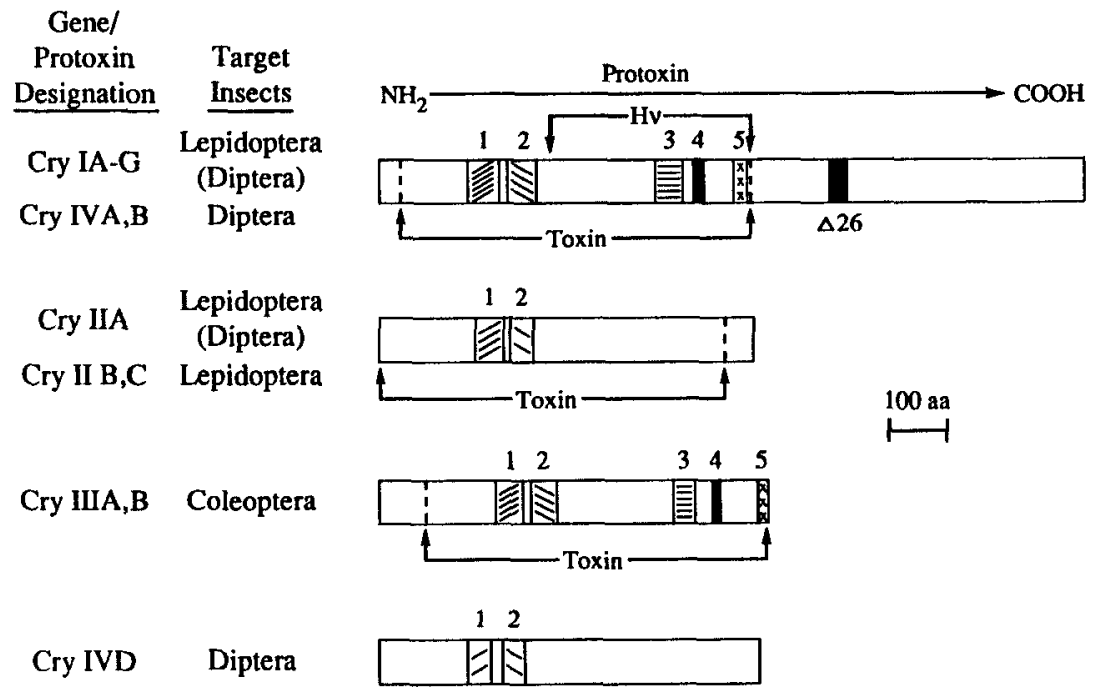

FIG. 4. General structural features of protoxins as deduced from gene sequences and other related data. Protoxins designated CryIA-CryIG, CryIVA, and CryIVB contain 1000-2000 amino acids, and the toxin is processed from within the amino half as shown. The CryIl, CrylII, and CryIVD protoxins are smaller, with processing to toxins as indicated (not known for CryIVD). Regions marked 1-5 are highly conserved among the CryI, CryIII, CryIVA, and CryIVB toxins and less so (pramarily regions 1 and 2) for the CryII and CryIVD toxins. The carboxl halves of the CryI, CryIVA, and CryIVB protoxins are also extensively conserved. A major difference is the deletion of 26 amino acids $(\Delta 26)$ in most of the CrylA(b) protoxins. Other portions of the toxins are more or less conserved within a particular class (i.e., those designated CryI or Cryll, etc.) but not between these classes. Reproduced with permission from Dr. Aronson.

sandwich (domain III). All the three domains have specific functional roles. The first domain is required for toxicity, and domain II is important for specificity. Although the function of Domain III near the carboxyl end was not defined, it is speculated that it may have a role in the processing of protoxin (Aronson, 1994, Martens et al., 1995) and channel-forming function (Chen et al., 1993).

Wu and Aronson (1992) induced localized mutagenesis in central helix of domain I and found loss of toxicity but not the capacity to bind midgut membranes. A synthetic peptide of helix 5 could insert itself into membrane and form ion channels that confirmed the importance of this helix (Gazit and Shai, 1995). Single site mutations in the conserved alternating arginine region affect ionic channels formed by CryIA(a), a Bt toxin (Schwartz et al., 1995). The assembly and organization of the $\alpha-5$ and $\alpha-7$ helices from the pore-forming domain of $B$. thuringiensis $\delta$-endotoxin is relevant to a functional model for pore formation (Gazit and Shai, 1995). Similarly, a truncated peptide corresponding to the domain I of 
CryIII $\beta 2$ was shown to be sufficient for membrane channel activity and ion efflux from artificial membrane vesicles (Van Tersch et al., 1994).

Mutations in domain I reduced the irreversible binding of toxin to BBMV ( Chen et al., 1995). The evidence that domain II is involved in specificity comes from the structural comparisons of CryIA toxins and construction of hybrid genes to analyze specificity domains (Schnepf et al.,1990; Ge et al., 1991). Chen et al. (1993) concentrated on the highly conserved block 4 of domain III and used site-directed mutagenesis to substitute other amino acids for arginine. Studies with these mutant proteins revealed that domain III is not only involved in structural stability and integrity of the toxin protein but also in function as an ion channel. Wabiko and Yasuda (1995) investigated the location of toxic border and the requirement of the nontoxic domain for high-level in vitro production of active toxin from $B$. thuringiensis protoxin.

\section{Screening for New Insecticidal Proteins and Genes}

As mentioned previously, the toxicity spectrum is being widened each year with the discovery of novel strains that are active against various organisms (Payne et al., 1995; Hickle and Payne, 1995; Kawalek et al., 1995). Following the early isolations of Bt from dead insect larvae, these bacteria have been found ubiquitously by using a novel enrichment technique that exploits unique germination properties of the spores (Martin and Travers, 1989) or by simply screening debris, such as soils, leaves, and dead larvae, for spore formers containing parasporal inclusions. An interesting example was the prevalence of isolates on the surfaces of leaves from various trees (Smith and Couche, 1991).

One of the most important aspects about establishing a Bt collection is to have a methodology with which one can rapidly and accurately characterize the strain, the toxin protein, and the gene. This is especially important if the differences among endotoxin genes, carried by a certain strain, are critical for its specificity and toxicity. The bioassay analysis is an exhaustive and time-consuming process because it is necessary to screen all the isolates in all of the target insects. Various methodologies have been described to simplify this process. The important approaches are

1. Southern blot analysis in search of homologous genes (Kronstad and Whiteley, 1986);

2. Reactivity to different monoclonal antibodies (Hofte and Whiteley, 1989); and

3. Electrophoretic analysis of PCR products using specific primers (Carozzi et al., 1991). 


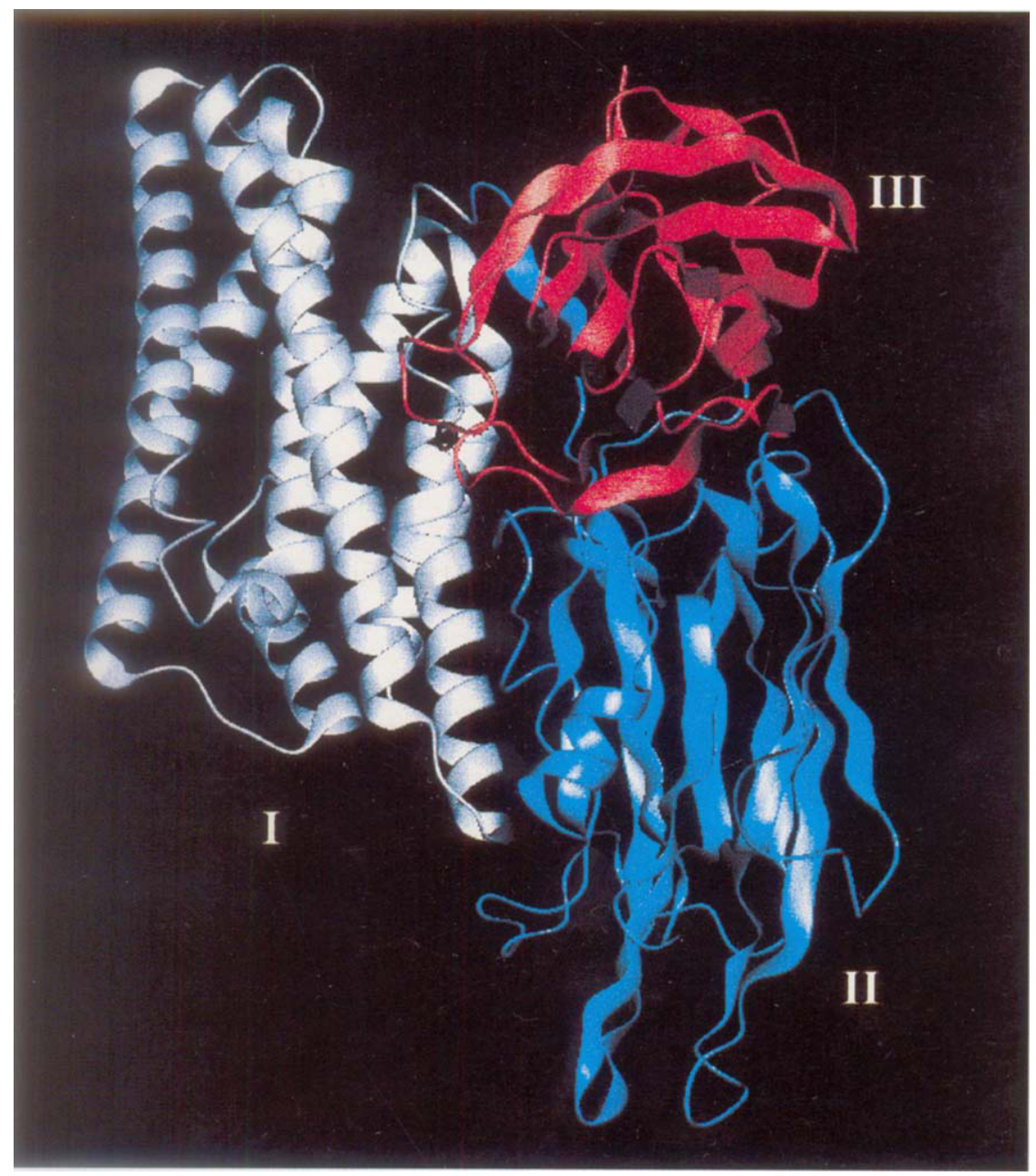

FIG. 5. A schematic ribbon diagram of the CryIIIA structure (Li et al., 1991). Domain I, the putative membrane insertion domain, is a 7-helix bundle (left); domain II, the putative receptor binding region, is an assembly of three $\beta$-sheets (lower right); domain III is a $\beta$-sandwich in which the $C$ terminus is buried (upper right). 
Among the three approaches, PCR analysis is considered to be the best choice because it permits a rapid determination of the presence or absence of a sequence, it is highly sensitive, relatively fast, and can be used routinely. Carozzi et al. (1991) described the sequences of 12 PCR primers that can distinguish three major classes of Bt toxin genes (cryI, cryIII, and $c r y I V$ ). However, it is important to delineate the genes in each subgroup because of the differential insect toxicity. PCR analysis of three cryIA subgroups was reported (Bourque et al., 1993). This analysis did not allow for the identification of the remaining cryI gene subgroups. Thus, it is important to develop a complete PCR set of primers that allows the identification of all reported cry genes.

Bravo and co-workers (Ceron et al., 1994) at the National University of Mexico designed four oligonucleotides that can be used to identify the strains that carry any of the cryI or cryIII genes. These primers were selected from a highly conserved region between cryI's or cryIII's genes by computer analysis using a Gene work 2 program that allows simultaneous alignment of several gene sequences. The primers were able to amplify a region ranging between 272 and $290 \mathrm{bp}$ from all the cryl genes and between 688 and $703 \mathrm{bp}$ from all cryIII genes. Strains with unique PCR product profiles were then characterized by using additional genespecific primers. A set of primers were designed that give a different molecular weight with each of the cryI and cryIII genes. These primers were selected from the highly variable region among all genes. They were designed to be used in mixtures of six to eight primers per reaction. By using these primers, all the cryI genes from $c r y I A$ to $c r y I G$, including subdivisions of cryIA genes as well as all the cryIII genes from cryIIIA to cryIIIE, could be identified (Ceron et al.,1994). The important feature of this screening method is that with each gene a precise molecular weight product is expected. Genes that produce different-sized products may represent novel genes. Using a similar approach, Kalman et al. (1993) found a novel cryIC gene. One limitation of the methodology, however, is that new genes from a Bt collection cannot be identified if the gene in question does not have any of the primer sequences. In addition, PCR screening does not provide information of the specific target insect of the novel gene.

Bravo et al. (1992a) developed an immunocytochemical technique to identify proteins that may have potential toxicity toward selected insects. This was based on a clear correlation between binding of toxic protein to its specific receptor localized in the microvilli of the midgut cells and toxicity. By using this methodology, toxins that are highly toxic to Diatraea grandiocella, Spodoptera frugiperda, and Rhopalosiphum maidis (aphid) were found. The proteins to be tested should be 
recognized by specific antibodies. They can also be labeled with biotin to be detected subsequently with streptavidin coupled to the peroxidase enzyme (Denolf et al., 1993).

Another approach to identify a toxin protein is to analyze its effects on the permeability of brush border membrane vesicles. Changes in membrane permeability can be measured fluorometrically with a fluorescent dye sensitive to changes in membrane potential. Uemura et al. (1992) used membrane vesicles from Bombyx mori and found that toxic proteins were able to produce clear effect on ion transport, whereas nontoxic proteins did not do so. The novel toxins that are able to modify the permeability of the membranes from a selected larva are expected to have a higher potential of being toxic.

Entomopathogenic bacteria belonging to Bacillaceae and the immunological relationship between their insecticidal toxins are being studied by cloning the toxin gene next to a Bacillus promoter in Escherichia coli. Recombinants are first screened with degenerate nucleotides probes based on the DNA sequence of the $\delta$-endotoxin gene. Recombinant plasmids from positive clones are transferred into toxin minus Bacillus strains and the protein produced is screened with antibodies directed against toxin from the wild-type Bacilli strain. This method can be adapted for screening large number of isolates with a wide variety of degenerate oligonucleotides.

\section{Mechanism of Action}

The target organ for Bt toxins is the insect midgut (Zimanyi et al., 1995). The midgut of the lepidopteran larvae is a simple, tubular epithelium that dominates the internal architecture of the insect. The tissue is composed of two major cell types: a columnar cell with a microvillate apical border and a unique goblet cell, containing a large vacuolar cavity, linked to the apical surface by an elaborate and tortuous "valve" (Cioffi, 1979). The " $\mathrm{K}^{+}$pump" is located in the apical membrane of the goblet cell, pumping $\mathrm{K}^{+}$from the cytoplasm into the cavity and thence to the gut lumen via the valve. This electrogenic $\mathrm{K}^{+}$transport is the predominant feature of the larval lepidopteran gut. Disruption of the activity of $\mathrm{K}^{+}$pump as a result of toxin-induced pore formation in the plasma membrane of the columnar cells leads to osmotic imbalance. Another important feature of the midgut is that the $\mathrm{pH}$ of the lumenal fluid is about 12, which is essential for dissolving the crystalline Bt protoxins, usually soluble only above $\mathrm{pH} 9.5$.

The crystalline protoxins are inactive. They are solubilized and then activated by gut trypsin like proteases (Milne and Kaplan, 1993, Tojo and Aizawa, 1983), which typically cleave some 500 amino acids from 
the $\mathrm{C}$ terminus of $130-\mathrm{kDa}$ protoxins and 28 amino acids from the $\mathrm{N}$ terminus, leaving a 65 to $55-\mathrm{kDa}$ protease-resistant toxic active core comprising the $\mathrm{N}$-terminal half of the protoxin (Hofte and Whiteley, 1989). The mature Cryl A toxin is cleaved at the amino-terminal R2 arginine residue (Nagamotsu et al., 1984) and the carboxyl-terminal $\mathrm{K}$ lysine residue (Bietlot et al., 1989). A tightly bound 20-kilobase heterogeneous DNA fragment is involved in the proper proteolytic processing of protoxin (Bietlot et al., 1993). The 70-kDa CryII, CryIII, and CryIVD proteins are naturally occurring truncated forms. The active toxins bind to specific receptors located on the apical brush border membrane of the columnar cells. Binding involves two steps, reversible (Hofmann and Luthy, 1986; Hofmann et al., 1988a) and irreversible (Ihara et al., 1993; Rajamohan et al., 1995). The irreversible step is followed by the insertion of the toxin into the apical membrane. Various studies revealed that there are many different toxin-binding protein receptors (Gill et al., 1992). Some of them were identified as 120 to $180-\mathrm{kDa}$ glycoproteins (Garczynski et al., 1991; Knowles et al., 1991; Oddou et al., 1991). In Manduca sexta, a $210-\mathrm{kDa}$ membrane protein is the CrylAb receptor (Vadlomudi et al., 1993, 1995). A 120-kDa aminopeptidase $\mathrm{N}$ has been reported as receptor for the Cry1 Ac toxin (Knight et al., 1994; Sangadala et al., 1994). Bacillus thuringiensis CrylAc $\delta$-endotoxin-binding aminopeptidase in the $M$. sexta midgut has a glycosyl phosphatidylinositol anchor (Garczynski and Adang, 1995). After binding to the specific receptor, the toxin inserts irreversibly into the plasma membrane of the cell leading to lesion formation. Three models were proposed to explain the role of toxin receptor in pore formation (Knowles and Dow,1993). The first model envisages that the receptor is itself a transmembrane channel that is activated by the toxin in a manner analogous to the ligand gating mechanism employed by neurotransmitters. The second possibility is that the toxin and receptor together form a pore. The third model explains that the receptor catalyzes toxin association or insertion into the membrane and plays no further role in pore formation. The receptor may either simply act as a handle to which the toxin binds or induce a conformational change in the toxin, thus enabling it to insert into the membrane.

The formation of toxin-induced pores in the columnar cell apical membrane allows rapid fluxes of ions. Different studies revealed that the pores are $\mathrm{K}^{+}$selective (Sacchi et al.,1986), permeable to cations (Wolfersberger, 1989), permeable to anions (Hendrick et al., 1989), or permeable to small solutes like sucrose, irrespective of the charge (Schwartz et al., 1991a). Using a simple light scattering assay, Carroll and Ellar (1993) found that the midgut membrane permeability in the presence of CrylAc was altered for cations, anions, and neutral solutes, as well as for water. It appears 
that the toxin forms or activates a relatively large aqueous channel in the membrane. The model proposed by Knowles and Dow (1993) placed emphasis on the cessation of the $\mathrm{K}^{+}$pump that leads to the swelling of columnar cells and osmotic lysis. The disruption of gut integrity results in the death of the insect from starvation or septicemia.

There seems to be a different mechanism of action with respect to CryIIA toxins.

Differences in the extent of solubilization may sometimes explain differences in the degree of toxicity among Cry proteins. Decreased solubility could be one potential mechanism for insect resistance (McGaughey and Whalon, 1992). English et al. (1994) compared the differences in solubility, binding to the brush border membrane, and ion channels formed by CryIIA and CrylAc toxins in Helicoverpa zea. The results showed unique attributes in the mode of action of CryIIA, which was less soluble than CryIAc and failed to bind to a saturable binding component on the midgut brush border membrane. In addition, voltage-dependent, nonselective channels were formed by this toxin in planar lipid bilayers. This behavior was reminiscent of several other channel-forming protein toxins of bacterial origin such as the E.coli active colicins, which have a strong voltage dependence. It was suggested that the unique mode of action of CryIIA may provide a useful tool in managing field resistance to $\mathrm{Bt}$ toxins.

Although the binding of the Cry toxins to receptors determines the insect specificity (Kronstad et al., 1983; Van Rie et al., 1990a), exceptions to correlation of binding and toxicity exist. CryIAc binds to ligand blots of Spodoptera exigua BBMV proteins without any toxicity to the insect larvae (Garczynski et al., 1991). CryIAb is more toxic to gypsy moth than CryIAc but does not bind as well to receptors on BBMV (Wolfersberger, 1990). Irreversible binding and ion-channel function directly correlate to toxicity in gypsy moth, thus unraveling the "Wolfersberger paradox" (Liang et al., 1995; Rajamohan et al., 1995; Liebig et al., 1995).

\section{Bt as a Biological Insecticide}

Bacillus thuringiensis is the most popular biological control agent with a worldwide projected sales of about $\$ 90$ million during 1995 (Lambert and Peferoen, 1992). Sixty-seven registered B. thuringiensis products have more than 450 uses and formulations (Dean and Adang, 1992; Rowe and Margoritis, 1987). Bacillus thuringiensis is the major pesticide against gypsy moth in forests (Twardus, 1989). Bacillus thuringiensis subsp. israelensis (BTI) is extensively used to control mosquitoes and blackflies (Becker and Margalit, 1993; de Barjac and Sotherland, 1990) 
Bacillus thuringiensis subsp. morrisoni and BTI carry four genes that encode mosquito and blackfly active toxins: $c r y I V A, c r y I V B, c r y I V C$, and cryIVD. BT also produces Cyt toxins that synergize the Cry toxins. Bacillus thuringiensis subsp. jegathesan encodes another potent mosquitocidal toxin immunologically related to CryIIA (Delecluse et al., 1995). Thus, Bt plays an important role not only in agriculture and forestry but also in the area of human health (Haider et al., 1986, 1987; Smith and Ellar, 1994; Orduz-Peralta et al., 1992).

The Bt toxin normally accumulates during the stationary phase (Bechtel and Bulla, 1976) with exceptions (Krieg et al., 1980). The earliest commercial production of Bt began in France in 1938 under the trade name Sporeine (Luthy et al., 1982). During the 1960s, several industrial formulations of Bt were manufactured in the United States, France, Germany, and Soviet Union. The isolation of the highly potent kurstaki variety by Kurstak in 1962 and by Dulmage in 1967 (Dulmage,1970) provided a much-needed boost to the commercialization of Bt. The HD1 isolate of Dulmage is still the active ingredient in most Bt products used against caterpillar pests in agriculture, horticulture, and forestry. The discovery of new strains of Bt widened the toxicity spectrum of bioinsecticides. The use of conventional Bt insecticides, however, was found to have limitations like narrow specificity, short shelf life, low potency, lack of systemic activity, and the presence of viable spores (Lambert and Peferoen, 1992). These problems are now overcome by various approaches that utilize the tools of molecular biology and genetic engineering as well as conventional microbiological methods (Ben-Dov et al., 1995).

\section{A. Construction of Novel Bt Strains by Conjugation}

The plasmid location of Bt toxin genes enabled the construction of novel Bt strains with microbial genetic approaches such as plasmid curing and conjugal transfer (Wiwat et al., 1995; Battisti et al., 1985). Conjugational transfer of native Bt plasmid between species of Bacillus is known to occur (Gonzalez et al., 1982; Reddy et al., 1987; Andrup et al., 1995). Expression of transformed plasmid-coded genes was analyzed by genotyping of crystal proteins and flagellar antigenicity. This particular set of studies employed conjugational transfer of an entire toxic polypeptide coding gene located on native plasmids. On the other hand, more versatility of the conjugational transfer-mediated approach was demonstrated with a mobilizable plasmid bearing a cloned gene coding for a variant Bt gene (Klier et al., 1983). Following the conjugational approach, scientists at Ecogen Corporation (USA) produced several bioinsecticides with broadened spectrum of toxicity (Gawron-Burke 
and Baum, 1991). For instance, the product "Foil" is made from a strain that carries toxin genes active against European corn borer (Lepidoptera) and Colorado potato beetle (Coleoptera).

Using the conjugational approach, Bora et al. (1994) transferred the crylAa gene of Bt into Bacillus megaterium, which resides in the cotton phyllosphere. Leaf bioassays of cotton plants, inoculated with a single spray of the transcipient, showed that there was protection to the cotton plants from Helicoverpa armigera. Enhanced production of insecticidal proteins occurs in $B$. thuringiensis strains carrying an additional crystal protein gene in their chromosomes (Kalman et al., 1995).

The conjugational approach to create novel Bt strains has certain limitations. Not all the Bt toxin genes are located on transferable plasmids. Second, the toxin protein with useful insecticidal activity may be synthesized at low amounts. Plasmid incompatibility could also be a problem. A significant advantage to the conjugal transfer approach is the simplified registration process for the Bt product. The U.S. Environmental Protection Agency treats transconjugants in a similar manner as it treats wild-type Bt isolates.

Another interesting approach to expand the insecticidal host range of $\mathrm{Bt}$ is to make use of the in vivo genetic recombination property (Baum et al., 1990). Lereclus et al. (1992) used insertion sequence IS232 to deliver CryIIIA gene into an isolate producing CryIAc toxin. Expression of the introduced gene did not alter the composition of the polypeptides normally produced by the strain. Novel Bt mutants, defective in sporulation but overproducers of toxin, have been isolated (Lereclus et al., 1995). They can be used safely as a biopesticide in silkworm-rearing areas . These mutants were shown to achieve effective control of $H$. armigera in field-grown chick-pea (Satyanarayana, et al., 1995).

\section{B. Construction of Recombinant Bt Strains}

Development of novel cloning vectors for Bt has made possible the construction of improved Bt strains for use as microbial insecticides. The use of Bt as the host organism offers many advantages. Native Bt strains can stably maintain and efficiently express several homologous Bt toxin genes. The ability to maintain multiple Bt toxin genes in a single recipient broadens the insecticidal activity in an additive or synergistic manner. Multiple toxin genes with differing modes of action or receptor-binding properties may reduce the chances of insects developing resistance (Tabashnik, 1994).

An essential element in the successful engineering of Bt strains is the availability of suitable cloning vectors. A number of convenient shuttle vectors, functional in E.coli and Bacillus species, have been constructed 
using replication origins from resident Bt plasmid (Baum et al., 1990; Gawron-Burke and Baum, 1991). Considering the stability of resident Bt plasmids, shuttle vectors derived from resident plasmids might exhibit good segregational stability. Lereclus and Arantes (1992) selected a replication origin from a small cryptic plasmid of Bacillus subtilis (pHT1030) that exhibits excellent segregational stability. They constructed shuttle vectors (Lereclus et al.,1989; Arantes and Lereclus, 1991; Figure 6) to introduce new Bt toxin genes into Bt strains. For instance, cryIIIA gene from Bacillus tenebrionis, when introduced into Bt. kurstaki HD119, was highly expressed without affecting the level of expression of native cry genes (Gamel and Piot, 1992). Shin et al., (1995) studied the distribution of cryV-type insecticidal protein genes in $B$. thuringiensis and cloned $c r y V$-type genes from $B$. thuringiensis subsp. kurstaki and $B$. thuringiensis subsp. entomocidus. Wu and Federici (1995) improved production of the insecticidal CryIVD protein in $B$. thuringiensis using $c r y I A(c)$ promoters to express the gene for an associated 20-kDa protein. Ely (1995) constructed insecticidal proteins from $B$. thuringiensis $\delta$-endotoxin and Androctonus australis neurotoxin AaHIT.

\section{Construction of Transgenic Microbes}

Cloned Bt toxin genes were introduced into a number of microbial hosts to create more stable and/or compatible agents for the toxin delivery. Monsanto scientists were the first to report the expression of the $c r y I A b$ gene in a root colonizing Pseudomonas at levels sufficient to kill lepidopteran larvae (Watrud et al., 1985). The gene was later cloned into Tn5 and transposed into the chromosome of six corn root-colonizing

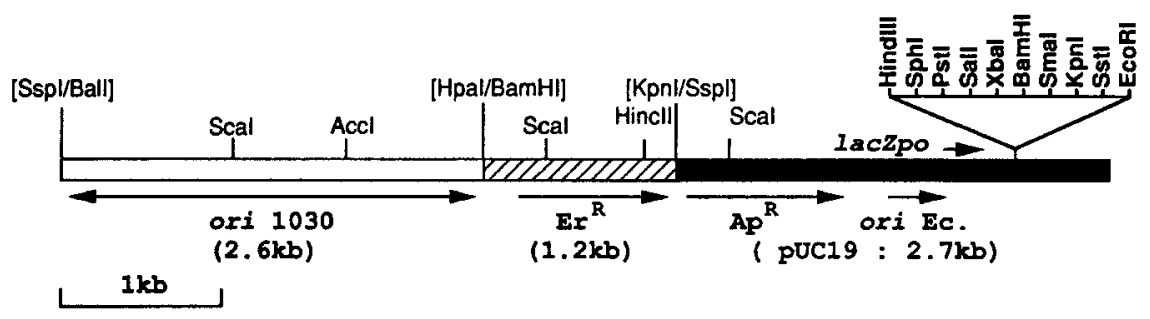

pHT304: $4 \pm 1$ copies/chromosome pHT315: $15 \pm 5$ copies/chromosome pHT370: $70 \pm 20$ copies/chromosome

FIG. 6. Vectors for cloning genes in B. thuringiensis and B. subtilis; Gene 1991 108: 115-119 (Reproduced with permission from D. Lereclus, Institut Pasteur, Paris). 
strains of Pseudomonas fluorescens and Agrobacterium radiobacter (Obukowicz et al., 1986). Following this, many groups developed Psuedomonas strains carrying Bt toxin genes. The recombinant Psuedomonas is killed by a proprietary chemical treatment that crosslinks the bacterial cell wall to yield a nonviable encapsulated bacterium surrounding the crystal protein (Cell-Cap product of Mycogen; Gaertner et al., 1993). Such a product is stable and safe for use in the environment.

An interesting example of a toxin gene in a foreign bacterium is the introduction of the cryIAC gene into the plant endophyte, Clavibacter xyli subsp. cyanodontis (Turner et al., 1991). Clavibacter resides in the xylem of Bermuda grass (Cynodon dactylon). It also colonizes the vascular system of corn when artificially inoculated. The recombinant bacterium can be inoculated into the stems to establish an endogenous supply of the toxin for protection against European corn borer. Recently, cryIAC was introduced into the chromosome of $C$. xyli by using an integrative plasmid vector that facilitates homologous recombination between the vector and the bacterial chromosome (Lampel et al., 1994). It is expected that this recombinant strain will show stability and in planta biological activity.

Introduction of Bt genes into root-nodulating bacteria, thereby providing protection to nodules from soil-dwelling pests, was accomplished by Nambiar et al. (1990). Recombinant Bradyrhizobium carrying cryIVD was produced and used to infect the roots of pigeon pea. The root nodule infestation by the larvae of the dipteran species, Rivella angulata, was reduced by $40 \%$. Bezdicek et al. (1994) introduced the cryIII gene into Rhizobium leguminosarum and R.meliloti by using a broad host range vector, pRK311, containing lac $Z$ promoter or nifH promoter. The recombinant rhizobia expressed the toxin in sufficient quantities within root nodules to significantly reduce feeding damage by the nodule-feeding insects, Sitona lineatus on Pisum sativum and Sitona hispidulus on Medicago sativa. The pRK311 plasmid remained stable in the rhizobia that were either free living or within nodules of the legumes. The engineered strains of R.leguminosarum were equally competitive with the wild-type strain. Udayasuriyan et al., (1995) transferred an insecticidal protein gene of $B$. thuringiensis into plant-colonizing Azospirillum that may be used to control root-feeding insects. Mosquitocidal Bt toxin genes were also shuffled between Bacillus sphaericus and Bt subsp. israelensis to extend the host range of the bacteria for mosquito larvae (Bourgouin et al., 1990; Bar et al., 1991). The cryIVA gene of Bt subsp. israelensis was also introduced into various unicellular cyanobacteria with the intent of providing a more accessible source of the toxin for filter-feeding dipteran larvae (Angsuthanasombat and Panyim, 1989; Chungiatupornchai, 1990; Soltes-Rak et al., 1993). 


\section{Baculoviruses as Bt Vectors}

It was demonstrated that insects are susceptible to a wide variety of virus infections (King et al., 1994). Many viruses are currently identified in insect hosts out of which baculoviruses carrying large, covalently closed, circular DNA genomes are useful as insect biocontrol agents. Two studies reported the insertion of Bt genes into the Autographa californica nuclear polyhedrosis virus genome (Martens et al., 1990; Merryweather et al., 1990). A full-length copy of the endotoxin coding sequence was inserted into the baculovirus genome in place of the polyhedrin gene-coding region. Martens et al. (1990) demonstrated that the protein produced in insect cells formed large crystals as inclusion bodies in the cytoplasm. When insect larvae were fed recombinant virus-infected cell extracts, the larvae perished. Merryweather et al. (1990) also cloned Bt gene upstream of the polyhedrin gene under the control of the AcNPV p10 promoter. When insects were given purified polyhedra in a bioassay, there was no effect on the larvae. It was possible that the protoxin produced by the virus remained as an intracellular protein and did not get processed and solubilized in the insect midgut for eventual toxicity. Addition of a suitable signal peptide sequence to the Bt toxin gene would facilitate secretion of the recombinant product from the cells into midgut and thereby improve its efficacy.

\section{E. Insect-Tolerant Transgenic Crop Plants}

An elegant, and perhaps the most effective delivery system for Bt toxins, is the transgenic plant (Stewart et al., 1995). The major benefits of this system are economic, environmental, and qualitative. In addition to the reduced input costs to the farmer, the transgenic plants provide season-long protection independent of weather conditions, effective control of burrowing insects difficult to reach with sprays, and control at all of the stages of insect development. The important feature of such a system is that only insects eating the crop are exposed to the toxin. Genetic transformation of almost all the major crop species is now feasible with the development of an array of techniques ranging from the Agrobacterium approach to electric discharge-mediated particle acceleration procedure (Finch, 1994).

The first Bt-transgenic plants were made in 1987 (Barton et al.,1987; Fischhoff et al., 1987; Vaeck et al., 1987). The plants expressed fulllength or truncated $\mathrm{Bt}$ toxin genes (cryIA) under the control of constitutive promoters. The expression of the toxin protein was very poor in the tobacco plants and the mortality of $M$. sexta larvae was only $20 \%$. Truncated $c r y I A$ genes coding for the toxic N-terminal fragment provided better protection to the tobacco and tomato plants. When compared to 
the plants transformed with full-length genes, the plants expressing truncated genes were more resistant to the larvae, and the highest reported level of toxin protein expression was about $0.02 \%$ of total leaf-soluble protein. Despite these low levels of expression, many of the plants were shown to be insecticidal to the larvae of $M$. sexta. However, many of the noctuid lepidopterans, which constitute a very serious group of insect pests, need higher amounts of Bt toxins for effective control. Gene truncation as well as the use of different promoters, enhancer sequences, and fusion proteins resulted in only limited improvement in Bt gene expression (Barton et al., 1987; Carozzi et al., 1992; Vaeck et al., 1987).

In 1990, researchers at Monsanto made a significant advancement in the expression of Bt genes in plants (Perlak et al., 1990). They noticed that Bt genes were excessively AT rich in comparison with normal plant genes. This bias in nucleotide composition of the DNA could have a number of deleterious consequences to gene expression because AT-rich regions in plants are often found in introns or have a regulatory role in determining polyadenylation. There are also instances in other eukaryotic systems in which AT-rich regions can signal rapid degradation of specific mRNAs. In addition, plants have a tendency to use $\mathrm{G}$ or $\mathrm{C}$ in the third base of redundant codons-A or $\mathrm{T}$ being rarer. Bt genes have the opposite tendency and because codon preference is thought to be linked to the abundance of the corresponding tRNAs, the overuse of rare codons would decrease the rate of synthesis of a Bt protein in plant cells.

Perlak et al. (1991) followed two approaches to modify the $c r y I A b$ and $c r y I A c$ genes. One approach included selective removal of DNA sequences predicted to inhibit efficient expression of Bt gene expression at both translational and mRNA levels by site-directed mutagenesis. These genes were termed partially modified (PM) genes. The other approach was to generate a synthetic gene with a fully modified (FM) nucleotide sequence, taking into account factors such as codon usage in higher plants, potential secondary structure of mRNA, and potential regulatory sequences. The PM-cryIAb gene is approximately $96 \%$ homologous to the native gene with a GC content of $41 \%$, with the number of potential plant polyadenylation signal sequences (PPSS) reduced from 18 to 7 and the number of ATTTA sequences reduced from 13 to 7 . The FM- $c r y I A b$ is approximately $79 \%$ homologous to the native gene, with a GC content of $49 \%$ and the number of PPSS reduced to 1 and all ATTTA sequences removed. The toxin protein levels in transgenic tobacco and tomato harboring these modified genes increased up to 100 -fold over levels seen with the wild-type Bt gene in plants.

Perlak et al. (1990) made a gene construct in which the first $1359 \mathrm{nu}-$ cleotides were derived from FM-cryIAb gene and the remaining se- 
quence from $P M$-cryIA $c$ gene. The variant gene was placed under the control of CaMV 35S promoter containing a duplicated enhancer region. Cotton-variety Coker 312 was transformed and the transgenic plants were shown to have total protection from Trichoplusia ni (Cabbage looper), $S$. exigua, and $H$. zea (cotton boll worm). The maximum level of toxin protein was $0.1 \%$ of total soluble protein.

The Monsanto group placed the FM-cryIAc gene under the control of Arabidopsis thaliana Rubisco small subunit promoter with its associated chloroplast transit peptide sequence (Wong et al., 1992). Transgenic tobacco plants expressing this gene provided a 10- to 20-fold increase in cryIAC mRNA and protein compared to gene constructs in which CaMV 35S promoter with duplicated enhancer region was used to express the same gene. The toxin protein was localized in the chloroplast and in the tobacco plants that produce the Bt protein nearly $1 \%$ of the total leaf protein had the highest levels of Bt toxin proteins yet reported. The enhancement of Bt toxin protein levels in tissues in which Rubisco expression is highest may lead to very effective control of certain insect pests that feed on leaves and other green tissues.

Ciba Seeds, a subsidiary of Ciba Geigy Company, used microprojectile bombardment with two plasmids (pCIB4431 and pCIB3064) of a proprietary corn line to produce a commercial cultivar (Federal Register 60 FR 9656-9657 1995). Plasmid pCIB4431 contains two different tissue-specific promoters each fused individually to a copy of a synthetic $c r y I A b$ gene. The $c r y I A(b)$ gene encodes the first 648 amino acids, with an insecticidal-active (Koziel et al., 1993) truncated product identical to that of the cryIAb gene of $B$. thuringiensis subsp. kurstaki strain HD-1 (Dulmage, 1970; Geiser et al., 1986; Hofte and Whiteley, 1989). The truncated synthetic gene accommodates the preferred codon usage for maize (Murray et al., 1989) that allows efficient expression of the cryIAb gene in plants (Perlak et al., 1991; Koziel et al., 1993). The modified gene has about $65 \%$ homology at the nucleotide level with the native gene and $\mathrm{G}+\mathrm{C}$ content has been altered from 38 to $65 \%$. The transgenic plant produces a protein that is identical to the first 648 amino acids of the full-length 1155-amino acid $\operatorname{Cry} I A(b)$ protoxin that occurs in nature. This truncated protein contains the portion of the native protein that is responsible for its insecticidal activity. The first promoter is derived from the corn phosphoenolpyruvate carboxylase (PEPC) gene (Hudspeth and Grula, 1989). It promotes expression of $c r y I A b$ in green tissue. The second pollen-specific promoter used is derived from a maize calcium-dependent protein kinase (CDPK) gene (Estruch et al., 1994). The combination of PEPC and pollen tissue-specific promoters provides high $c r y I A b$ gene expression in leaves and pollen, where it is 
most effective in controlling European corn borer. PEPC intron 9 of the corn phosphoenolpyruvate carboxylase gene (Hudspeth and Grula, 1989 ) is located between the $\operatorname{cryIA(b)}$ structural gene and the $35 \mathrm{~S}$ terminator. Its presence also increases the expression level of the $c r y I A(b)$ gene (Luehrsen and Walbot, 1991). The 3' untranslated termination sequences (CaMV) $35 \mathrm{~S}$ from the cauliflower mosaic virus (CaMV) is present adjacent to the PEPC intron 9 . Its function is to provide a polyadenylation site and it has been described previously (Rothstein et al., 1987; Sanfacon et al., 1991). The activity of the pollen-specific promoter, associated with its native CDPK structural gene in maize, is not modulated by calcium levels in the plant. Rather, the catalytic activity of the mature CDPK protein in majze is affected by calcium levels. Therefore, fusion of this promoter sequence to the $c r y I A b$ will not manifest in any changes in the calcium requirements of corn. High levels of CrylAb protein were obtained using both promoter configurations in the transgenic maize plants. Hybrid maize plants resulting from crosses of transgenic elite inbred plants with commercial inbred lines were evaluated for resistance to European corn borer (Ostrinia nubilalis) under field conditions. Plants expressing high levels of the insecticidal protein exhibited complete resistance to heavy infestations of the pest.

A similar approach was followed by Fujimoto et al. (1993) to enhance $c r y I A b$ gene expression in rice plants. Based on the codon usage of known rice genes, $66.6 \%$ of the codons in the coding region of the $c r y I A b$ gene were altered. The overall $\mathrm{G}+\mathrm{C}$ content of the modified gene was $59.2 \%$, whereas that of the original gene was $37.6 \%$. The monocotyledons, including cereals, have higher $\mathrm{G}+\mathrm{C}$ contents than those from dicots. The level of expression of the modified gene in transgenic rice was $0.05 \%$ of total soluble leaf protein. The plants were significantly resistant to two lepidopteran rice pests, leaf folder (Cnaphalocrosis medinalis) and stem borer (Chilo suppressalis).

Following the successful attempts to control lepidopteran insects by using FM-cryIA genes, synthetic cryIII genes were also made and expressed in tobacco and potato plants, primarily for the control of Colorado potato beetle (Coleoptera) (Sutton et al., 1992; Perlak et al., 1993). The Russet Burbank potatoes were protected from damage by all insect stages in the laboratory, and dramatic protection was discernible at multiple field locations (Perlak et al., 1993).

Van der Salm et al. (1994) developed transgenic tobacco and tomato plants expressing two Bt genes, cryIAb and $c r y I C$, specific toward lepidopteran insects. Both of the genes were partially modified to remove sequence motifs that affect mRNA stability in plant cells. The expression of a $c r y I A b-c r y I C$ fusion gene resulted in protection against $S$. exigua, Heliothis virescens, and $M$. sexta. This study demonstrated the potential 
of expressing translational fusions not only to broaden the insect resistance of transgenic plants, but also to simultaneously employ different gene classes in resistance management strategies (see Section VIII).

Recently, researchers at Calgene, in collaboration with Maliga and Svab (1993) (Waksman Institute), expressed a cryIA gene in tobacco chloroplasts using chloroplast transformation vectors and particle bombardment technique. The transplastomic tobacco expressed the $\mathrm{Bt}$ toxin at very high levels and achieved complete control of lepidopteran larvae (McBride et al., 1995). The advantages of such a system are manyfold:

1. The Bt gene does not need any modification because the chloroplast transcriptional and translational apparatus are typically prokaryotic;

2. It is possible to have many copies of the Bt gene in each cell;

3. The expression of the gene will be high if driven by promoters like $r b c L$ and $c a b$; and

4. Because chloroplasts are maternally inherited, there is no risk of pollen transfer of the Bt gene to related plant species or weeds. The disadvantage of this approach lies in its tissue specificity. For instance, stem and fruit borers cannot be controlled following this method.

Most of the transgenic plants developed so far contained the Bt toxin genes under the control of the powerful, constitutively active $35 \mathrm{~S}$ promoter. However, expression of the Bt toxin gene throughout the plant growth and development and in tissues in which it is not needed may encourage resistance development by the target insect (Harris, 1991). Kumar and Sharma (1994) reviewed alternative approaches like using wound and light-inducible promoters, tissue-specific promoters, and promoters responsive to chemical sprays being used in different laboratories.

\section{Resistance Development and Management Strategies}

Resistance will eventually develop as a result of widespread use of any biopesticide. Resistance to $B$. thuringiensis endotoxins has already been developed in the laboratory (Tabashnik, 1994) that can be initiated by alteration of the target of insect-toxin interaction (Gould et al. 1992; MacIntosh et al., 1991; Van Rie et al., 1990b). In insect-tolerant transgenic plants, solubility and proteolytic processing are bypassed because only the toxin-soluble core of the Cry protein is produced. Transgenic plants with multiple genes coupled with other management strategies might slow resistance development. Although resistant mosquitoes have been selected with individual toxins such as CryIIA, due to the combination of four Cry toxins and the spore, mosquito resistance will be hard to evolve against BTI (Georghiou, 1994; Goldman et al., 1986). Bt had been used as a biopesticide for more than two decades. Evolution 
of resistance was presumed unlikely because of the lack of reports of substantial resistance development in open field populations (de Barjac, 1987). However, resistance to Bt was documented in field populations of diamondback moth (Tabashnik et al., 1990, 1991; Rabindra et al., 1995). These and many other reports confirmed doubts raised by the results of laboratory selection for resistance to $\mathrm{Bt}$ in several major pests (McGaughey, 1985; McGaughey and Beeman, 1988). Various aspects of insect's resistance to Bt viz. laboratory selection, resistance risk assessment, variation among conspecific populations, mechanisms, cross-resistance, genetics, stability, fitness costs, and management were recently reviewed (McGaughey, 1994; Tabashnik, 1994; Kennedy and Whalon, 1995). In this section, the mechanisms involved in resistance and strategies to manage its development are explored.

Intensive selection pressure on insect populations inevitably leads to the development of resistance. The resistance could be achieved by different mechanisms ranging from the point of protoxin ingestion to the insertion of toxin in the membrane. The factors affecting the binding of toxin to the receptor would result in selective resistance. On the other hand, those steps utilized by all the toxins viz. proteolysis of protoxins, conformational alterations, and membrane insertion may lead to crossresistance. Studies revealed that midgut $\mathrm{pH}$ and the nature of proteases probably were not involved in achieving resistance (Kinsinger and McGaughey, 1979; Johnson et al., 1990). Reduced binding of Bt toxin to the brush border membrane of the midgut epithelium was identified as a primary mechanism of resistance in Plodia interpunctella (Van Rie et al., 1990c) and Plodia xylostella (Bravo et al., 1992 a,b; Ferre et al., 1991). Studies with radioactive-labeled CrylAb showed that a 50 -fold reduction in binding was correlated with a 100 -fold reduction in toxicity of CryIAb in a resistant versus a susceptible strain of $P$. interpunctella (Van Rie et al., 1990c). A strain of $P$. xylostella from the Phillippines showed a 200-fold resistance to CrylAb and little or no binding of the toxin to the midgut epithelial membrane compared to a susceptible strain.

In contrast to the results for $P$. interpunctella and $P$. xylostella, two independent studies on $H$. virescens found no clear association between toxin binding and resistance to CryIAb or CryIAc (MacIntosh et al., 1991; Gould et al., 1992). The only evidence against involvement of the binding step in the mechanism of both resistance and specificity was presented by Wolfersberger (1990). He found that in Lymantria dispar there was a negative relationship between binding affinity and toxicity of two different Bt toxins toward a single strain of insect. That is, the more toxic protein is bound with less affinity than the less toxic one. 
Wolfersberger's results are consistent with the idea that there could be differences in toxicity as well as differences in binding affinity.

An observation of considerable significance was that of resistance development in $P$. interpunctella to multiple toxins (McGaughey and Whalon, 1992). Selection of $P$. interpunctella colonies resistant to $\mathrm{Bt}$ isolates, known to contain multiple protoxins, resulted in the isolation of colonies resistant to several toxins (McGaughey and Johnson, 1993). The apparent frequency of such resistant colonies appears to be too high for two or more independent mutations, each altering a specific receptor. It is possible that resistance is due to the mutation of one locus affecting the ability of a variety of toxins as in the $H$. virescens colony with broad resistance (Gould et al., 1992). It is also possible that these receptors may somehow interact or cluster, such that a single mutation affects the binding properties of several toxins (Aronson, 1994).

With the realization that insects can develop resistance to Bt, attention is now being focused on developing deployment strategies that might delay or prevent its evolution. Theoretically, resistance to conventionally sprayed Bt could develop slower and be narrower in scope and easier to manage than resistance to synthetic organic insecticides because Bt has a shorter residual period and much narrower spectrum of biological activity. Expression of Bt toxins in other bacteria or addition of ultraviolet blockers to formulations can extend the persistance of Bt, making it comparable to organic insecticides (Tabashnik, 1994). Expression of Bt in transgenic plants may continuously select pests intensively for resistance because insects are exposed to Bt even when they are not causing economic damage (Mallet and Porter, 1992). Various strategies were suggested to tackle the problem of resistance development and have been summarized by Whalon and McGaughey (1993). These tactics were patterned after those used or proposed for use in managing chemical insecticide resistance and typically involve variations of the following: (i) rotation or alteration of toxins, (ii) mixtures or sequences of toxins, (iii) provision of refuges, (iv) ultrahigh doses of toxin, and (v) temporal and spatial expression of Bt toxin genes in transgenic plants.

\section{A. Rotations}

Rotation or alteration of Bt toxins, insecticides, and cultural or biological control strategies is probably the simplest approach to resistance management. Success with this tactic depends on restoring susceptibility when selection pressure is discontinued or changed to another gene, toxin, or insecticide. However, rotations among toxins that confer cross-resistance to each other have limited value (Gould, 1988; 
Gould et al., 1992). Studies indicating considerable instability of resistance to Bt in P. xylostella (Hama et al, 1992) and H. virescens (Sims and Stone, 1991), and one case of negative cross-resistance in P. interpunctella (Van Rie et al., 1990c), suggest that rotations might slow resistance development in certain situations. However, McGaughey and Beeman (1988) found that high levels of resistance in P. interpunctella were stable for long periods, and in such cases rotations may not be effective.

\section{B. MiXTuRES OF ToXins}

Mixtures of toxins is also a relatively simple tactic that is possible in both conventional applications and transgenic plants. It is based on the idea that if resistance to each component in a mixture is rare, then individuals with resistance to all components will be exceedingly rare or absent. However, extensive cross-resistance among different Bt toxins may reduce the likelihood that mixtures will effectively control resistance (Gould et al., 1992). Many field populations of P. xylostella evolved resistance to $B$ formulations that contain mixtures of up to five toxins (Tabashnik et al., 1990). In laboratory tests, $P$. interpunctella readily became resistant to a mixture of two $\mathrm{Bt}$ strains that contained at least six CryIA, CryIC, and CryII toxins (McGaughey and Johnson, 1992). Further research is needed to elucidate the patterns of response of different insect species to Bt mixtures before a suitable recommendation is made that assures prevention of resistance.

\section{ReFuges}

Facilitating the survival of susceptible insects is one of the best approaches to slow resistance development. Results from modeling studies demonstrated that refuges and immigration of susceptible insects into pest populations can slow the evolution of resistance (Tabashnik, 1990). This was supported by the results from laboratory experiments on $H$. virescens and P. xylostella (Gould and Anderson, 1991; Schwartz et al., 1991b). Spatial and temporal employment of refuges and factors affecting their efficacy need to be worked out at the field level. Spatial refuges facilitate random mating between susceptible and resistant adults and may limit movement of larvae between Bt-treated and untreated plants (Mallet and Porter, 1992). Spatial refuges can be provided among tissues within plants by ensuring tissue-specific expression of the Bt gene, among plants within fields by growing transgenic and nontransgenic plants in a defined ratio, or between fields in which neigh- 
boring fields are sown with plant varieties differing in their susceptibility to a given insect.

\section{Toxin Doses}

There are two approaches dealing with high as well as low doses of Bt toxin application to circumvent resistance problems. The low-dose approach includes reduced rates and frequency of application, reduced thoroughness of application, and transgenic plants with low expression of toxin. This tactic aims to reduce populations only slightly or slow larval development to the point that the number of generations per year is reduced or natural enemies are more effective. However, this approach is not practical because farmers and pest managers prefer products that prevent any damage.

Denholm and Rowland (1992) advocated a high-dose strategy in conjunction with untreated refuges as a potential means of managing resistance development in transgenic plants. This approach maintains that constitutive and continuous expression of Bt toxins in transgenic plants may be sufficient to kill all of the heterozygotes in a population (McGaughey and Whalon, 1992). This approach is not possible with conventional Bt applications because foliar applications never cover the entire plant and do not persist long enough to achieve "continuous" expression of Bt (Whalon and McGaughey, 1993).

A high dose can be defined as that which consistently kills heterozygotes (Whalon and McGaughey, 1993). Determination of this dose is dependent on the genetics of resistance. It would be lowest in cases in which resistance is inherited recessively and highest in cases in which it is completely dominant. Because homozygous-resistant individuals are at a very low frequency early in the evolution of resistance and suitable refuges provide a continuous source of susceptible individuals, this tactic should be quite durable (Whalon and McGaughey, 1993).

An extremely high dose or ultrahigh dose is possible where target insects are very sensitive and Bt expression in transgenic plants is very high ( $1 \%$ of total protein). This dose is sufficiently high to kill even homozygous-resistant individuals. However, doubts persist because doses as high as $268 \mathrm{~g} /$ liter of a $B$. thuringiensis subsp. kurstaki formulation could not kill resistant individuals of $P$. xylostella (Tabashnik et al., 1993). As discussed previously, binding affinity for toxins is a primary mechanism of resistance in $P$, xylostella. If binding affinity approaches zero, attempts to kill resistant insects with high doses may be futile (Tabashnik, 1994). 


\section{E. GENE EXPRESSION}

Spatial, temporal, and inducible expression of Bt genes in transgenic plants is one of the features of management strategies. Continuous and constitutive expression of Bt genes results in significant selection pressure on pest populations. Tissue-specific (leaf, stem, root, boll, pod, or seed), stage-specific (vegetative or reproductive), and wound-specific promoters are now available that can be employed to rationalize Bt gene expression. Chemical sprays like that of salicylic acid can be used to induce Bt gene expression at will by using suitable promoters (Williams et al., 1992). All these approaches need to be experimentally verified in a thorough manner.

Unfortunately, no transgenic plants have been experimentally evaluated with Bt-resistant insects. More work is needed to assess the role of behavior and other biological, ecological, and genetic factors in resistance development to $\mathrm{Bt}$ and to $\mathrm{Bt}$ transgenic plants.

\section{Epilogue}

Both chemical and microbial insecticides are currently used for insect control. Among chemical insecticides organophosphates (Counter, Dyfonate, Lorsban, Thimet, Parathion, and Penncap), pyrethroids (Ambush, Pounce, and Capture), carbamate (Furadan) and others (Asana XL) are used. Although organophosphates and pyrethroids can be effective, careful insect surveillance is required. Applications must be carefully timed to reach certain insect populations before the insects bore into the stalk and other plant organelles, and repeated applications are often necessary.

A class of insecticidal proteins, known as $\delta$-endotoxins, are produced as parasporal crystals by $B$. thuringiensis in nature. These proteins are quite selective in their toxicity to specific organisms. The crystal proteins are typically produced as large protoxins. Following ingestion by a susceptible insect, the protoxin is solubilized in the alkaline insect gut, and then activated by digestive enzymes to yield a smaller protein. The activated protein binds to specific receptors in the insect midgut and brings about cell lysis by formation of pores. Cessation of feeding and death of the insects follow. These naturally occurring insecticidal proteins have been commercially produced and used as insecticides for decades. An extensive body of safety testing and experience supports their lack of toxicity to humans and animals and the absence of adverse effects on nontarget organisms and the environment.

Bacillus thuringiensis var. kurstaki (Btk) preparations are registered for use on corn, vegetables, cotton, deciduous nuts, and fruits. As crystalline powder formulations, Btk has been used commercially as an in- 
secticide under the trade name Dipel. Availability of recombinant DNA technology has provided the opportunity of expressing these biocidal proteins in various organisms (Table IV). The production of insect control protein by various crop plants represents a potentially important new option in pest control and an attractive alternative to external application of insecticides. Transgenic plants producing the insecticidal proteins are quite effective in controlling various crop pests, even though only minute quantities are produced (Table V). Plants are being engineered to preferentially express the insect control protein in desired tissues, while minimizing its production in other plant tissues in which it is not needed for control of the target pest.

Transgenic plants hold great promise as an important new tool in integrated pest management programs. This technology allows the crop plant to deliver its own means of protection against insect attack. The expected result is a very specific and directed biological control method that is environmentally sound and that can be expected to reduce the need for manual and chemical inputs by the grower. Commercial bioinsecticide formulations are generally ineffective in controlling ECB on corn in which topical applications of the powder do not reach the inside of the plant tissue where the insects bore and feed (Bartels and Hutchison, 1995). Such transgenic crops provide farmers a means of controlling a serious insect pest that is not easily controlled by current chemical pesticides. Other advantages include: (i) reducing the risks associated with environmental spills or misapplication of chemical insecticides; (ii) eliminating unwanted effects on beneficial insect populations (which can be susceptible to conventional chemical applications)-these beneficial insects can, in turn, further reduce the reliance on chemical means of pest control; and (iii) reducing the consumption of fossil fuels required to deliver chemical inputs by machinery.

Because of the environmental pollution and associated toxicity with chemical insecticides, biological insect control has a bright future. Various mutant forms of insecticidal proteins with improved biological activity will be created in the future by fusing diverse domains (Hon'ee et al., 1990) and in vitro mutagenesis of genes that codes for these biological agents (Aronson et al., 1995; Rajamohan et al., 1995).

Mosquitoes and blackflies are vectors of a multitude of diseases of man and animals through transmission of pathogenic viruses, bacteria, protozoa, and nematodes. At the molecular level, the processed toxin binds to a specific receptor molecule located on the plasma membrane of the susceptible insect midgut. This initial binding could account for the specificity of the toxin. After binding to the receptor, the toxin creates small pores in the gut membrane leading to colloidal-osmotic lysis 
TABLE IV

BT GenEs Expressed in Various ORGanisms

\begin{tabular}{|c|c|c|c|}
\hline Gene & Donor & Recipient plant & Institution \\
\hline cry & $\mathrm{Bt}$ & Clavibacter & Crop genetics \\
\hline \multirow[t]{3}{*}{$\operatorname{cry} I A(a)$} & $\mathrm{Bt}$ & Cranberry & University of Wisconsin \\
\hline & Btk & Cotton & Agracetus \\
\hline & Btt & Potato & ARS \\
\hline \multirow[t]{7}{*}{$\operatorname{cryIA}(b)$} & Bt & $\begin{array}{l}\text { Corn } \\
\text { Tobacco }\end{array}$ & $\begin{array}{l}\text { Ciba-Geigy; Monsanto } \\
\text { Rohm and Haas; Sandoz }\end{array}$ \\
\hline & Btk & Corn & Ciba-Geigy; Northrup King \\
\hline & & Cotton & Monsanto; Northrup King \\
\hline & & Rapeseed & Agrigenetics \\
\hline & & Tobacco & $\begin{array}{l}\text { Ciba-Geigy; North Carolina State } \\
\text { University }\end{array}$ \\
\hline & & Tomato & $\begin{array}{l}\text { Campbell; Monsanto; Northrup } \\
\text { King; Rogers NK }\end{array}$ \\
\hline & Btt & Corn & Northrup King \\
\hline \multirow[t]{16}{*}{$\operatorname{cry} I A(c)$} & $\mathrm{Bt}$ & Corn & Monsanto \\
\hline & & Cotton & $\begin{array}{l}\text { American Cyanamid; Miles; } \\
\text { Monsanto }\end{array}$ \\
\hline & & Potato & Michigan State University \\
\hline & & Rapeseed & University of Georgia \\
\hline & Btk & Amelanchier laevis & Dow \\
\hline & & Apple & University of California/Davis \\
\hline & & Brassica oleracea & Cornell University \\
\hline & & Clavibacter & Crop Genetics \\
\hline & & Corn & Crop Genetics; Monsanto \\
\hline & & Cotton & $\begin{array}{l}\text { CalGene; Monsanto; Northrup } \\
\text { King }\end{array}$ \\
\hline & & Poplar & University of Wisconsin \\
\hline & & Rapeseed & University of Chicago \\
\hline & & Spruce & University of Wisconsin \\
\hline & & Tobacco & CalGene \\
\hline & & Tomato & $\begin{array}{l}\text { Agrigenetics; Campbell; } \\
\text { Monsanto }\end{array}$ \\
\hline & & Walnut & $\begin{array}{l}\text { ARS; University of California/ } \\
\text { Davis }\end{array}$ \\
\hline cryIB & Btt & Potato & ARS \\
\hline cryIIA & Btk & Potato & Monsanto \\
\hline \multirow[t]{5}{*}{ CryIIIA } & Bt & Eggplant & Rutgers University \\
\hline & & Potato & Monsanto \\
\hline & Btk & Potato & ARS; Monsanto \\
\hline & Btt & Eggplant & Rutgers University \\
\hline & & Potato & Frito-Lay; Monsanto \\
\hline
\end{tabular}


TABLE V

BT ENGINEERED CROPS ${ }^{a}$

\begin{tabular}{ll}
\hline \multicolumn{1}{c}{ Crop } & \multicolumn{1}{c}{ Company/institution } \\
\hline Corn & $\begin{array}{c}\text { Ciba-Geigy; DeKalb; Dow Elanco; Hunt-Wesson; Monsanto; } \\
\text { Mycogen; North Carolina State University; Northrup King; } \\
\text { Pioneer Hi-Bred; Rogers NK Seed }\end{array}$ \\
Rice & Louisiana State University \\
Agracetus; American Cyanamid; Calgene; Delta and Pine Land; & Miles; Monsanto \\
Apple & University of California \\
Potato & Frito-Lay; Michigan State University; Monsanto; U.S. \\
& Department of Agriculture \\
Tomato & Campbell; Monsanto; Rogers NK Seed; Sandoz \\
Eggplant & Rutgers University \\
Canola (oilseed rape) & AgriGenetics; University of Chicago; University of Georgia \\
Alfalfa & Mycogen \\
Walnut & U.S. Department of Agriculture \\
Tobacco & Agrigenetics; Calgene; Ciba-Geigy; North Carolina State \\
& University; Rohm and Haas \\
Poplar & University of Wisconsin \\
Spruce & University of Wisconsin \\
Cranberry & University of Wisconsin \\
\hline
\end{tabular}

${ }^{a}$ Since 1987, 14 crops and trees engineered to express the Bt toxin gene have been field tested in the United States by the companies and institutions shown in the table. Source: Applications and notifications submitted since 1987 to the U.S. Department of Agriculture to field test genetically engineered plants. Other Bt plants are under development, but have not reached the field test stage.

and kills the larvae rapidly. The receptor for an insecticidal protein of $B$. thuringiensis has been cloned (Vadlomude et al., 1995).

Rajamohan et al., (1995) and Chen et al., (1995) studied the binding of the toxin to the receptor. They showed that the binding is a two-step process in which the irreversible binding is directly correlated to insect toxicity and not the initial binding. The amino acids of CryIAb toxin involved in the irreversible binding to the receptor are F37, and G374 of CryIAb toxin. Rajamohan et al., (1994) also identified the amino acids (365-370) essential for the toxicity of another toxin, CryIAa, to $B$. mori. They also constructed several mutant toxins that increased toxicity, especially to gypsy moth (a forest pest insect) about 7-10 times more potent than the parental toxin. Hybrid wide-spectrum toxins, by switching the toxicity determining regions of different Cry toxins, may improve toxicity and yield a toxin with multiple insect specificity through protein engineering. 


\section{ACKNOWLEDGMENTS}

The authors are grateful to Professor Don Dean for providing the colored photograph and to Dr. Rajamohan for critical reading of the manuscript.

\section{REFERENCES}

Adams, L. F., Visick, J. E., and Whiteley, H. R. (1989). J. Bacteriol. 171, 521-530.

Adang, M. J., Brody, M. S., Cardineou, G, Eagan, N., Roush, R. T., Shewmaker, C. K., Jones, A., Oakes, J. V., and McBride, K. E., (1993). Plant Mol. Biol. 21, 1131-1145.

Adang, M. J., Staver, M. J., Rocheleau, 'T. A., Leighton, J., Barker, R. F., and Thompson, D. V. (1985). Gene 36, 289-300.

Agaisse, H., and Lereclus, D. (1995). J. Bacteriol. 117, 6027-6032.

Agaisse, H., and Lereclus, D. (1994a). Mol Microbiol 13, 97-107.

Agaisse, H., and Lereclus, D. (1994b). J. Bacteriol, 176, 4734-4741.

Ahmad, W., and Ellar, D. J. (1990). FEMS Microbiol. Lett. 68,97-104.

Aronson, A. I., Han, E.-S., McGaughey, W., and Johnson, D. (1991). Appl. Environ. Microbiol. 57, 981-986.

Andrup, L., Bendixen, H. H., and Jensen, G. B. (1995). Plasmid 33(3), 159-167.

Angsuthanasombat, C., and Panyim, S. (1989). Appl. Environ. Microbiol. 55, 2428-2430. Arantes, O., and Lereclus, D. (1991). Gene 108, 115-119.

Aronson, A. I. (1986). Microbiol. Rev. 50, 1-24.

Aronson, A. I. (1994). In "Bacillus subtilis and Other Gram Positive Bacteria" (A. L. Sonenshein, J. A. Hoch, and R. Losick, eds.), pp. 953-963. American Society of Microbiology, Washington, DC.

Aronson, A. I., Wu D., and Zhang, C. (1995). J. Bacteriol. 177(14), 4059-4065.

Asano, S, and Hori, H. (1995). Appl. Entomol. Zool. 30(2), 369-374.

Asano, S., Indrasith, L. S., and Hori, H. (1995). Appl. Entomol. Zool. 30(1), 153-158.

Bar, E., Litman-Hurwitz, S., Rohamins, E., Kenyan, A., and Sandler, N. (1991). J.Invertebr. Pathol. 57, 149-158.

Bartels, D. W., and Hutchison, W. D. (1995). J. Econ. Entomol. 88, 380-386.

Barton, K. A., Whiteley, H. R., and Yang, N.-S. (1987). Plant Physiol. 85, 1103-1109.

Battisti, L., Green, B. D., and Thorne, C. D. (1985). J.Bacteriol. 162, 543-550.

Baum, J. A. (1995). Patent WO 9502058 A2, U.S. 89986 (930708), U. S. 266408 (940624).

Baum, J. A., Coyle, D. M., Gilbert, M. P., Jany, C. S., and Gawron-Burke, C. (1990). Appl. Environ. Microbiol. 56, 3420-3428.

Bechtel, D. B., and Bulla, L. A., Jr. (1976). J. Bacteriol. 127, 1472-1481.

Becker, N., and Margalit, J. (1993). In "Bacillus thuringiensis an Environmental Biopesticide: Theory and Practice" (P. F. Entwistle, P. F. Cory, M. J. Bailey, and S. Higgs, eds.). Wiley, New York.

Ben-Dov, E., Boussiba, S., and Zaritsky, A. (1995). J. Bacteriol. 177, 2851-2857.

Berliner, E. (1915). Z. Angew. Entomol. 2, 29-56.

Bezdicek, D. F., Quinn, M. A., Forse, L., Heron, D., and Kahn, M. L. (1994). Soil Biol. Biochem. 26, 1637-1646.

Bietlot, H. P., Carey, P. R., Pozsgay, M., and Kaplan, H. (1989). Anal. Biochem. 181, 212-215. Bietlot, H. P., Schernthaner, J. P., Milne, R. E., Clairmont, F. R., Bhella, R. S., and Kaplan, H. (1993). J. Biol. Chem. 268, 8240-8245.

Bora, R. S., Murty, M. G., Shenbagarathai, R., and Sekar, V. (1994). Appl. Environ. Microbiol. 60, 214-222.

Boss, M., Masson, L., and Brousseau, R. (1990). Nucleic Acids Res. 18, 7443. 
Bourgouin, C., Delecluse, A., de la Torre, F., and Szulmajster, J. (1990). Appl. Environ. Microbiol. 56, 340-344.

Bourque, S. N., Valero, J. R., Mercier, J., Lavoie, M. C., and Levesque, R. C. (1993). Appl. Environ. Microbiol., 59, 523-527.

Bourque, S. N., Valero, J. R., Lavoie, M. C., and Levesque, R. C. (1994). Appl. Environ. Microbiol. 61, 1623-1626.

Bradley, D., Harkey, M. A., Kim, M.-K., Bievers, K. D., and Bauer, L. S. (1995). J. Invertebr. Pathol. 65(2), 162-173.

Bravo, A., Hendrickx, K., Jansens, S., and Peferoen, M. (1992a). J. Invertebr. Pathol. 60, 247-253.

Bravo, A., Jansens, S., and Peferoen, M. (1992b). J. Invertebr. Pathol. 60, 237-246.

Brizzard, B. L., and Whiteley, H. R. (1988). Nucleic Acids Res. 16, 2723-2724.

Brousseau, R., Saint-Onge,A., Prefontaine, G., Mason, L., and Cabana, J. (1993). Appl. Environ. Microbiol. 59, 114-119.

Brown, K. L., and Whiteley, H. R. (1992). J. Bacteriol. 174, 549-557.

Bulla, L. A., Jr., Costilow, R. N., and Sharpe, E. S. (1978). Adv. Appl. Microbiol. 23, 1-18.

Burtseva, L. I., Burlak, V. A., Kalmikova, G. V., de Barjac, H., and Lecadet, M.-M. (1995). J. Invertebr. Pathol. 66, 92-93.

Shin, S.-K., Park, S. H., Choi, S. K., Koo, B.-T., Lee, S.-T., and Kim, J. I. (1995). Applied Environ. Microbiol. 61(6), 2402-2407.

Capalbo, D. M. F. (1995). A Memorias do Instituto Oswaldo Cruz Rio de Janeiro 90(1), pp. 135-138.

Carlson, C. R., Caugant, D. A., and Kolsto, A.-B. (1994). Appl. Environ. Microbiol. 60, 1719-1725.

Carlson, C. R., and Kolsto, A. B. (1993). J.Bacteriol. 175, 1053-1060.

Carlton, B. C., and Gonzalez, J. M. (1985). In "The Molecular Biology of Bacilli" (J. Hoch, ed.), pp. 211-249. Academic Press, New York.

Carozzi, N. B., Kramer, V. C., Warren, G. W., Evola, S., and Koziel, M. G. (1991). Appl. Environ. Microbiol. 57, 3057-3061.

Carozzi, N. B., Warren, G. W., Desai, N., Jayne, S. M., Lotstein, R., Rice, D. A., Evola, S., and Koziel, M. G. (1992). Plant Mol. Biol. 20, 539-548.

Carroll, J., and Ellar, D. J. (1993). Eur. J.Biochem. 214, 771-778.

Ceron, J., Covarrubias, L., Quintero, R., Ortiz, A., Ortiz, M., Aranda, E., Lina, L., and Bravo, A. (1994). Appl. Environ. Micrbiol. 60, 353-356.

Chak, K.- F., Tseng, M.-Y., and Yamamoto, T. (1994). Appl. Environ. Microbiol. 60, 2304-2310. Chen, X. J., Lee, M. K., and Dean, D. H. (1993). Proc. Natl. Acad. Sci. USA 90, 9041-9045. Chen, X. J., Curtiss, A., Alcantara, E., and Dean, D. H. (1995). J. Biol. Chem. 270, 6412-6419. Chestukhina, G. G., Kostina, L. I., Mikhailova, A. L., Tyurin, S. A., Klepikova, F. S., and Stepanov, V. M. (1982). Arch. Microbiol. 132, 159-162.

Choma, C. T., Surewicz, W. K., and Kaplan, H. (1991). Biochem. Biophys. Res. Commun. 179, 933-938.

Chungiatupornchai, W., Hofte, H., Seurinck, J., Angsuthanasombat, C., and Vaeck, M. (1988). Eur. J. Biochem. 173, 9-16.

Chungjatupornchai, W. (1990). Curr. Microbiol. 21, 283-288.

Cioffi, M. (1979). Tissue Cell 11, 467-479.

Covarrubias, L., Cervantes, L., Covarrubias, A.,Soberon, X.,Vichido, I., Blanco, A., Kupersztoch, Y., and Bolivay, F. (1981). Gene 13, 25-35.

Crickmore, N., Zeigler, D. R., Feitelson, J., Schnepf, E., Lambert, B., Lereclus, D., Baum, J., and Dean, D. H. (1996). Genes Microbial. Rev., in press.

Dankocsilc, C., Donovan, W. P., and Jany, C. S. (1990). Mol. Microbiol. 4, 2087-2094. 
Dardenne, F, Seurinck, J., Lambert, B., and Peferoen, M. (1990). Nucleic Acids Res. 18, 5546. Dean, D. H., and Adang, M. J. (1992). In "Plant Protein Engineering" (P. R. Shewry and S. Gutteridge, eds.) Cambridge Univ. Press, Cambridge, UK.

de Barjac, H., and Sotherland, D. J. (1990). "Bacteriol Control of Mosquitoes and Blackflies." Rutgers Univ. Press, New Brunswick, NJ.

De Barjac, H. (1987). In "Biotechnology in Invertebrate Pathology and Cell Culture" (K.Maramorosch, ed.), pp. 63-73. Academic Press, San Diego.

De Barjac, H., and Bonnefoi, A. (1962). Entomophaga 1, 5-31.

De Barjac, H., and Franchon, E. (1990). Entomophaga 35, 233-240.

De Block, M., Botterman, J.,Vandewiele, M., Dockx, J., Thoen, C., Gossele, V., Movva, N. R., Thompson, C., Van Montagu, M., and Leemans, J. (1987). EMBO J. 6, 2513-2518.

Delecluse, A., Bourgouin, C., Menou, G., Lereclus, D., Klier, A., and Rapoport, G. (1990). In "Genetics and Biotechnology of Bacilli" (M. M. Zukowski, A. T. Ganesan, and J. A. Hoch, eds.), pp. 181-190. Academic Press, New York.

Delecluse, A., Rosso, M., and Ragni, A. (1995). Appl. Environ. Microbiol. 61, 4230-4235.

Delucca, A. J., II, Palmgren, M. S., and de Bariac, H. (1984). J. Invertebr. Pathol. 43, 437-438.

Delucca, A. J., II, Simonson, J. G., and Larson, A. D. (1981). Can J. Microbiol. 27, 865-870.

Denholm, I., and Rowland, M. W. (1992). Annu. Rev. Entomol. 37, 91-112.

Denolf, P., Jansens, S., Peferoen, M., Degheele, D., and Van Rie, J. (1993). Appl. Environ. Microbiol. 59, 1828-1837.

Dervyn, E., Poncet, S., Klier, A., and Rapoport, G. (1995). J. Bacteriol. 177(9), 2283-2291.

Diamond, T. V., and Lee, I. H. (1995). Abstr. Papers Am. Chem. Soc. 209(1-2), AGRO 54.

Donovan, W. P., Rupar, M. J., Slaney, A. C., Malvar, T., Gawron-Burke, M. C., and Johnston, T. B. (1992). Appl. Environ. Microbiol. 58, 3921-3927.

Donovan, W. P., Gonzalez, J. M., Gilbert, M. P., and Dankocsik, C. (1989). J. Biol. Chem. 264, 4740 .

Donovan, W. P., Gonzalez, J. M., Jr., Gilbert, M. P., and Dankocsik, C. (1988a). Mol. Gen. Genet. 214, 365-372.

Donovan, W. P., Dankocsik, C., and Gilbert, M. P., (1988b). J. Bacteriol. 170, 4732-4738.

Drahos, D. J., Hemming, B. C., and McPherson, S. (1986). Bio/Technology 4, 439-444.

Drobniewski, F. A. (1994). J. Appl. Bacteriol. 76, 101-109.

Du, C., Martin, P. A. W., and Nickerson, K. W. (1994). Appl. Environ. Microbiol. 60, 3847-3853.

Dulmage, H. T. (1970). J. Invertebr. Pathol. 15, 232-239.

Earp, D. J., and Ellar, D. J., (1987). Nucleic Acids Res. 15, 3619.

Ely, S. (1995). Patent: PCT International; WO 9511305 A2 *GB 9321469 (931018).

English, L., Robbins, H. L., Von Tersch, M. A., Kulesza, C. A., Ave, D., Coyle, D., Jany, C. S., and Slatin, S. L. (1994). Insect. Biochem. Mol. Biol. 24, 1025-1035.

English, L. H., Le Reoddy, T., and Bosticin, A. E. (1991). Insect Biochem. 21, 177-184.

Estruch, J. J., Kadwell, S., Merlin, E., and Crossland, L. (1994). Proc. Natl. Acad. Sci. USA 91, 8837-8841.

Farrar, R. R., Jr., and Ridgway, R. L. (1995). J. Entomol. Sci. 30(1), 29-42.

Feitelson, J.J., Payne, J., and Kim, L. (1992). Biotechnology 10, 271-276.

Ferre, J., Real, M. D., Van Rie, J., Jansens, S., and Peferoen, M. (1991). Proc. Natl. Acad. Sci. USA B8, 5119-5123.

Finch, R. P. (1994). In "Molecular Biology in Crop Protection" (G.Marshal and D.Walters, eds.), pp. 1-37. Chapman \& Hall, London.

Fischhoff, D. A., Bowdish, K. S., Perlak, F. J., Marrone, P. G., McCormick, S. M., Niedermeyer, J. G., Dean, D. A., Kusano-Kretzer, K., Meyer, E. J., Rochester, D. E., Rogers, S. G., and Fraley, R. T. (1987). Biotechnology 5, 807-813. 
Fujimoto, H., Itoh, K., Yamamoto, M., Kyozuka, J., and Shimamoto, K. (1993). Biotechnology 11, 1151-1155.

Gaertner, F. H., Quick, T. C., and Thompson, M. A. (1993). In "Advanced Engineered Pesticides" (L. Kim, ed.), pp. 73-83. Dekker, New York.

Galivrt, N. J., Sivosubramanian, N., and Federici, B. A. (1987). Curr. Microbiol. 16, 171-174.

Gamel, P. H., and Piot, J. C. (1992). Gene 120, 17-26.

Gangurde, R. P., and Shethna, Y. I. (1995). World J. Microbiol. Biotechnol. 11(2), 202-205.

Garczynski, S. F., Crim, J. W., and Adang, M. J. (1991). Appl. Environ. Microbiol. 57, 2816-2820.

Garczynski, S. F., and Adang, M. J. (1995). Insect Biochem. Mol. Biol. 25(4), 409-415.

Gawron-Burke, C., and Baum, J. A. (1991). Genet. Engg. 13, 237-263.

Gazit, E., and Shai, Y. (1995). J. Biol. Chem. 270(6), 2571-2578.

Ge, A. Z., Shivarova, N. I., and Dean, D. H. (1989). Proc. Natl. Acad. Sci. USA 86, 4037-4041.

Ge, A. Z., Rivers, D., Milne, R., and Dean, D. H. (1991). J. Biol. Chem. 266, 17954-17958.

Geiser, M., Schweitzer, S., and Grimm, C. (1986). Gene 48, 109-118.

Georghiou, G. P. (1994). Proc. VIth Int. Collog. Invertebr. Pathol. Microb. Control, Montpellier, France.

Gibson, D. M., Greenspan, G. L., Krasnoff, S. B., and Ketchum, R. E. B. (1995). J. Econ. Entomol. 88(2), 270-277.

Gill, S. S., Cowles, E. A., and Pietrantonio, P. V. (1992). Annu. Rev. Entomol. 37, 615-636.

Gleave, A. P., Hedges, R. J., and Broadwell, A H. (1992). J. Gen. Microbiol. 138, 5542.

Goldberg, L. J., and Margalit, J. (1977). Mosquito News 37, 355-358.

Goldman, I. F., Arnold, J., and Cariton, B. C. (1986). J. Invertebr. Pathol. 47, 317-324.

Gonzalez, J. M., Jr., and Cariton, B. C. (1982). In "Genetic Exchange: A Celebration and a New Generation" (U. Streips, S. Goodgal, W. Guild, and G. Wilson, eds.). Dekker, New York.

Gonzalez, J. M., Brown, B. J., and Carlton, B. C. (1982). Proc. Natl. Acad. Sci. USA 79, 6951-6955.

Gonzalez, J. M., Jr., Dulmage, H. T., and Carlton, B. C. (1981). Plasmid 5, 351-365.

Gordon, R. E., Haynes, W. C., and Pang, C. H. N. (1973). "The Genus Bacillus." Washington, DC: Agricultural Research Service, USDA.

Gould, F. (1988). Trends Ecol. Evol. 3, 515-518.

Gould, F. W. (1968). "Grass Systematics." McGraw-Hill, New York.

Gould, F., and Anderson, A. (1991). Environ. Entomol. 20, 30-38.

Gould, F., Martinez-Ramirez, A., Anderson, A., Ferre, J., Silva, F. J., and Moar, W. J. (1992). Proc. Natl. Acad. Sci, USA 89, 7986-7988.

Gould, F., Follett, P., Nault, B., and Kennedy, G. G. (1994). In "Advances in Corn Pest Management: Biology and Management” (G. W. Zehnder, M. L. Powelson, R. K. Jansson, and K. V. Raman, eds.), pp. 255-277. American Phytopathological Society, St. Paul, MN.

Hallauer, A. R., Russell, W. A., and Lamkey, K. R. (1988). In "Corn and Corn Improvement, Third Edition" (G. F. Sprague and J. W. Dudley, eds.), pp. 463-564. American Society of Agronomy, Crop Science Society of America, and Soil Science Society of America, Madison, WI.

Hama, H., Suzuki, K., and Tanaka, H. (1992). Appl. Entomol. Zool. 27, 355-362.

Harris, M. K. (1991). Science 253, 1075.

Hendrickx, K., de Loof, A., and Van Mellaert, H. (1989). Comp. Biochem. Physiol. C 95, 241-245.

Herrnstadt, C., Gilroy, T. E., Sobieski, D. A., Bennett, B. D., and Gaertner, F. H. (1987). Gene 57, 37-46. 
Hickle, L. A., and Payne, J. (1995). Patent U.S. 93199 (930715).

Hitchcock, A. S., and Chase, A. (1951). "Manual of the Grasses of the United States," pp. 1051. U.S. Government Printing Office, Washington, DC.

Hofmann, C., and Luthy, P. (1986). Arch. Microbiol. 146, 7-11.

Hofmann, C., Luthy, P., Hutter, R., and Pliska, V. (1988a). Eur. J. Biochem. 173, 85-91.

Hofmann, C., Vanderbruggen, H., Hohe, H., Van Rie, J., Jansens, S., and Van Mellaerit, H. (1988b). Proc. Natl. Acad. Sci. USA 85, 7844-7848.

Hofte, H., and Whiteley, H. R. (1989). Microbiol. Rev. 53, 242-255.

Hofte, H., Soetaert, P., Jansens, S., and Peferoen, M. (1990). Nucleic Acids Res. 18, 5545.

Hofte, H., Seurinck, J., Van Houltven, A., and Vaeck, M. (1987). Nucleic Acids Res. 15, 7183.

Hofte, H., deGreve, H., Seurinck, J., Jansens, S., Mahillon, J., Ampe, C., Vandekerskhove, J., vanMontagu, M., Zabeau, M., and Vaeck, M. (1986). Eur. J. Biochem. 161, 273-280.

Hohe, H., Van Rie, J., Jansens, S., Van Houtven, A., Vanderbruggen, H., and Vaeck, M. (1988). Appl. Environ. Microbiol. 54, 2010-2017.

Holm, L., Pancho, J. V., Herberger, J. P., and Plucknett, D. L. (1991). "A Geographical Atlas of World Weeds," pp. 340-343. Wiley, New York.

Hon'ee,G.,Vriezen,W., and Visser, B. (1990). Appl. Environ. Microbiol. 56, 823-825.

Honee, G., vanderSalm, T., and Visser, B. (1988). Nucleic Acids Res. 16, 6240.

Hudspeth, R. L., and Grula, J. W. (1989). Plant Mol. Biol. 579-589.

Husz, B. (1928). Int. Corn Borer Invest. Sci. Rep. 1, 191-193.

Ihara, H., Kuroda, E., Wadano, A., and Himeno, M. (1993). Biosci. Biotech. Biochem. 57, 200.

Ishiwata, S. (1901). Dainihan Sanbshi Kaiho 9, 1-5.

Jensen, G. B., Wilcks, A., Petersen, S. S., Damgaard, J., Baum, J. A., and Andrup, L. (1995). J. Bacteriol. 177(10), 2914-2917.

Johannessen, C. L., and Parker, A. Z. (1989). Econ. Bot. 43, 164-180.

Johnson, D. E., Brookhart, G. L., Kramer, K. J., Barnett, B. D., and McGaughey, W. H. (1990). J. Invertebr. Pathol. 55, 235-243.

Jones, T. J., and Khachatourians, G. G. (1995). Can. J. Plant Sci. 75(1), 303.

Jung, Y.-C., Kim, S.-U., Son, K.-H., Lee, H.-H., and Bok, S.-H. (1995). J. Microbiol. Biotechnol. 5, 138-142.

Kaelin, P., Morel, P., and Gadani, F. (1994). Appl. Environ. Microbiol. 60, 19-25.

Kalman, S., Kiehne, K. L., Libs, J. L., and Yamamoto, T. (1993). Appl. Environ. Microbiol. 59, 1131-1137.

Kalman, S., Kiehne, K. L., Cooper, N., Reynoso, M. S., Yamamoto, T. (1995). Appl. Environ. Microbiol. 61, 3063-3068.

Kawalek, M. D., Benjamin, S., Lee, H. L., and Gill, S. S. (1995). Appl. Environ. Microbiol. 61, 8 2965-2969.

Kennedy, G. G., and Whalon, M. E. (1995). J. Econ. Entomol. 88(3), 454-460. King, L. A., Possee, R. D., Hughes, D. S., Atkinson, A. E., Palmer, C. P., Marlow, S. A., Pickering, J. M., Joyce, K. A., Lawrie, A. M., Miller, D. P., and Beadle, D. J. (1994). Adv. Insect Physiol., in press.

Kinsinger, R. A., and McGaughey, W. H. (1979). J. Econ. Entomol. 72, 346-349.

Klier, A., Fargette, F., Ribier, J., and Rapoport, G., (1982). EMBO J. 1, 791-799.

Klier, A., Bourgouin, C., and Rapoport, G. (1983). Mol. Gen. Genet. 191, 257-262.

Knight, P. J. K., Crickmore, N., and Ellar, D. J. (1994). Mol. Microbiol. 11, 429-436.

Knowles, B. H. (1994). Adv. Insect Physiol. 24, 275-308.

Knowles, B. H., and Dow, J. A. T. (1993). Bioessays 15, 469-476.

Knowles, B. H., Knight, P. J. K., and Ellar, D. J. (1991). Proc. R. Soc. London B 245, 31-35. Kolsto, A.-B., Carlson, C., Lindback, T., and Kvaloy, K. (1995). J. Cell. Biochem. Suppl. 0(19A), 110. 
Kondo, S., Tamura, N., Kunitate, A., Hattori, M., and Akashi, A., Agric. Biol. Chem. 51(2), $455-463$.

Koni, P. A., and Ellar, D. J. (1995). J. Mol. Biol. 229, 319-327.

Koziel, M. G., Beland, G. L., Bowman, C., Carozzi, N. B., Crenshaw, R., Crossland, L., Desai, N., Hill, M., Kadwell, S., Launis, K., Lewis, K., Maddox, D., McPherson, K., Meghji, M. R., Merlin, E., Rhodes, R., Warren, G. W., Wright, M., and Evola, S. V. (1993). Bio/Technology 11, 194-200.

Krieg, V. A., Engler, S., and Rieger, M. (1980). Pflanzenschutz Umweltschutz 53, 129-133.

Kronstad, J. W., and Whiteley, H. R. (1986). Gene 43, 29-40.

Kronstad, J. W., Schnepf, H. E., and Whiteley, H. W. (1983). J. Bacteriol. 154, 419-428.

Kumar, P. A., and Sharma, R. P. (1994). J. Plant Biochem. Biotechnol. 3, 3-8.

Lamberit, B., Hofte, H., Annys, K., Jansens, S., Soetaert, P., and Peferoen, M. (1992). Appl. Environ. Microbiol. 58, 2536-2542.

Lambert, B., Van Audenhove, K., Theunis, W., Agouda, R., Jansens, S., Seurinck, J., and Peferoen, M. (1992). Gene 110, 131-132.

Lambert, B., and Peferoen, M. (1992). Bioscience 42 112-121.

Lampel, J. S., Canter, G. L., Dimock, M. B., Kelly, J. L., Anderson, J. J., Uratani, B. B., Foulke, J. S., and Turner, J. T. (1994). Appl. Environ. Microbiol. 60, 501-508.

Lee, C.-S., and Aronson, A. I. (1991). J. Bacteriol. 173, 6635-6638.

Lee, M. K., Milne, R., Ge, A. Z., and Dean, D. H. (1992). J. Biol. Chem. 267, 3115-3121.

Lereclus, D., and Arantes, O. (1992). Mol. Microbiol. 6, 35-46.

Lereclus, D., Arantes, O., Chaufaux, J., and Lecadet, M.-M. (1989). FEMS Microbiol. Lett. 60, 211-218.

Lereclus, D., Vallade, M., Chaufaux, J., Arantes, O., and Rambaud, S. (1992). Bio/Technology 10, 418-421.

Lereclus, D., Agaisse, H., Gominet, M., and Chaufaux, J. (1995). Bio/Technology 13(1), 67-71.

Li, J., Carroll, J., and Ellar, D. J. (1991). Nature 353, 815-821.

Li, S. Y., Fitzpatrick, S. M., and Isman, M. B. (1995). Can. Entomol. 127, 271-273.

Liang, Y., and Dean, D. H. (1995). Mol. Microbiol. 13(4), 569-575.

Liang, Y., Patel, S., and Dean, D. H. (1995). J. Biol. Chem., in press.

Liebig, B., Stetson, D. L., and Dean, D. H. (1995). J. Insect Physiol. 41, 17-22.

Lu, H., Rajamohan, F., and Dean, D. H. (1994). J. Bacteriol. 176, 5554-5559.

Luehrsen, K. R., and Walbot, V. (1991). Mol. Gen. Genet. 225, 81-93.

Luthy, P., Cordier, J., and Fischer, H. (1982). In "Microbial and Viral Pesticides" (E. Kurstak, ed.), pp. 35-74. Dekker, New York.

MacIntosh, S. C., Stone, T. B., Jokerst, R. S., and Fuchs, R. L. (1991). Proc. Natl. Acad. Sci. USA 88, 8930-8933.

Mallet, J., and Porter, P. (1992). Proc. R. Soc. London Ser. B. 250, 165-169.

Martens, J. W. M., Honee, G., Zuidema, D., vanLent, J. W. M., Visser, B., and Vlak, J. M. (1990). Appl. Environ. Microbiol. 56 Appl., 2764-2770.

Martens, J. W. M., Visser, B., Vlak, J. M., and Bosch, D. (1995). Mol. Gen. Genet. 247(4), $482-487$.

Martin, P. A. W., and Travers, R. S. (1989). Appl. Environ. Microbiol. 55, 2437-2442.

Masson, L., Marcotte, P., Prtfonitaine, G., and Broussevu, R. (1989). Nucleic Acids Res. $17,446$.

McBride, K. E., Svab, Z., Schaef, D. J., Hogan, P. S., Stalker, D. M., and Maliga, P. (1995). Biotechnology 13, 362-365.

McCammon, S. L., and Medley, T. L. (1990). In "The Molecular and Cellular Biology of the Corn" (M. E. Vayda, and W. D. Park, eds.), pp. 233-250. CAB International, Wallingford, UK. 
McGaughey, W. H. (1985). Science 229, 193-195.

McGaughey, W. H. (1994). Agric. Ecosystems Environ. 49, 95-102.

McGaughey, W. H., and Beeman, R. W. (1988). J. Econ. Entomol. 81, 28-33.

McGaughey, W. H., and Johnson, D. E. (1993). J. Econ. Entomol. 85, 1594-1600.

McGaughey, W. H., and Whalon, M. E. (1992). Science 258, 1451-1455.

McIntosh, S. C., Stone, T. B., Jokerst, R. S., and Fuchs, R. L. (1991). Proc. Natl. Acad. Sci. USA 88, 8930-8933.

McLinden, J. H., Sabourin, J. R., Cleirk, B. D., Gensler, D. R., Workman, W. E., and Dean, D. H. (1985). Appl. Environ. Microbiol. 50, 623-628.

McPherson, A., Jurnak, F., Singh, G. J. P., and Gill, S. S. (1987). J. Mol. Biol. 195, 755-757.

Meadows, M. P., Ellis, D. J., Butt, J., Jarrett, P., and Burges, H. D. (1992). Appl. Environ. Microbiol. 58, 1344-1350.

Merryweather, A. T., Weyer, V., Harris, M. P. G., Hirst, M., Booth, T., and Possee, R. D. (1990). J. Gen. Virol. 71, 1535-1544.

Milne, R., and Kaplan, H. (1993). Insect. Biochem. Mol. Biol, 23, 663-673.

Murray, E. E., Lotzer, J., and Eberle, M. (1989). Nucleic Acids Res. 17, 477-498.

Nagamotsu, Y., Itai, Y., Hatonaka, C., Funatsu, G., and Hayashi, K. (1984). Agric. Biol. Chem. 48, 611-619.

Nambiar, P. T. C., Ma, S. W., and Iyer, V. N. (1990). Appl. Environ. Microbiol. 56, 2866-2869.

Nishimoto, T., Yoshisue, H., Ihara, K., Sakai, H., and Komano, T. (1994). FEBS Lett. 348, 249-254.

Obukowicz, M.-G., Perlak, F. J., Kusano-Kretzmer, K., Mayer, E. J., Bolten, S. L., and Watrud, L. S. (1986). J. Bacteriol. 168, 982-989.

Oddou, P., Hartmann, H., and Geiser, M. (1991). Eur. J. Biochem. 202, 673-680.

Odell, J. T., Nagy, F., Chua N.-H. (1985). Nature 313, 810-812.

Oeda, K., Oshie, K., Shimizu, M., Nakamura, K., Yamamoto, H., Nakayama, I., and Ohkawa, H. (1987). Gene 53, 113-119.

Ogiwara, K., Hori, H., Minami, M., Takeuchi, K., Sato, R., Ohba, M., and Iwahana, H. (1995). Curr. Microbiol. 30, 227-235.

Ordus-Peralta, S., Diaz, T., Restrepo, N., and Roias, W. (1992). J. Invertebr. Pathol. 60, 107-108.

Parry, J. M., Turnbull, P. C. B., and Gibson, J. R. (1983). "A colourful Atlas of Bacillus species" Wolfe Medical, London.

Payne, J., Narva, K., E., Uyeda, K. A., Stadler, C. J., and Michaels, T. E. (1995). Patent U.S. 5436002, U.S. 129610 (930930), *U.S. 647399 (910129), *U.S. 708266 (910528),

${ }^{\star}$ U.S. 746751 (910821), *U.S. 977350 (921117), *U.S. 93199 (930715).

Pedersen, J. C., Damgaard, P. H., Eilenberg, J., and Hansen, B. M. (1995). Can. J. Microbiol. 41(2), 118-125.

Peferoen, M. (1992). In "Plant Genetic Manipulation for Crop Protection" (A. M. R. Gatehouse, V. A. Hilder, and D. Boulter, eds.J, pp. 135-154. C.A.B International, Oxon.

Perlak, F. J., Deaton, R. W., Armstrong, T. A., Fuchs, R. I., Sims, S. R., Greenplate, J. T., and Fischhoff, D. A. (1990). Bio/Technology 8, 939-943.

Perlak, F. J., Fuchs, R. L., Dean, D. A., McPherson, S. L., and Fischhoff, D. A. (1991). Proc, Natl. Acad. Sci. USA 88, 3324-3328.

Perlak, F. J., Stone, T. B., Muskopf, Y. M., Petersen, L. J., Parker, G. B., McPherson, S. A., Wyman, J., Love, S., Reed, G., Bisser, D., and Fischhoff, D. A. (1993). Plant Mol. Biol. 22, 313-321.

Rabindra, R. J., Justin, C. G. L., and Jayaraj, S. (1995). Indian J. Agric. Sci. 65(2), 152-153. Rabinovitch, L., Jesus, F. F. D., Cavados, C. F. G., Zahner, V., Momen, H., Silva, M. H. L. D., Dumanoir, V. C., Frachon, E., Lecadet, M. M. (1995). Memorias do Instituto Oswaldo Cruz Rio de Janeiro 9o(1), 41-42. 
Rajamohan, F., Alcantara, E., Lee, M. K., Chen, X. J., Curtiss, A., and Dean, D. H. (1995). J. Bacteriol. 177, 2276-2282.

Reddy, A., Battisti, L., and Thorne, C. B. (1987). J. Bacteriol. 169, 5263-5270.

Rothstein, S. J., Lahners, K. M., Lotstein, R. J., Carozzi, N. B., Jayne, S. M., and Rice, D. A. (1987). Gene 53, 153-161.

Rowe, G. E., and Margoritis, A. (1987). CRC Crit. Rev, Biotechnol. 6, 87-127.

Sacchi, V. F., Parenti, P., Hanozet, G. M., Giordana, B., Luthy, P., and Wolfersberger, M. G. (1986). FEBS Lett. 204, 213-218.

Salama, H. S., Zaki, F. N., and Ragaei, M. (1995). 68(1), 15-17.

Sanchez, J., Svennerholm, A.-M., and Holmgren, J. (1988). FEBS Lett. 241, 110-114.

Sanchis, V., Lereclus, D., Menou, G., Chaufaux, J., and Lecadet, M. M. (1988). Mol. Microbiol. 2, 393-404.

Sanfacon, H., Brodmann, P., and Hohn, T. (1991). Genes Dev. 5, 141-149.

Sangadala, S., Walters, F. S., English, L. H., and Adang, M. J. (1994). J. Biol. Chem. 269, 10088-10092.

Satyanarayana, V. A., Khanuja, S. P. S., and Sharma, R. P. (1995). J. Plant Biochem. Biotechnol. 4, 81-84.

Schnepf, H. E., Wong, H. C., and Whiteley, H. R. (1985). J. Biol. Chem. 260, 6264-6272.

Schnepf, H. E., Tomczak, K., Ortega, J. P., and Whiteley, H. R. (1990). J. Biol. Chem. 265, 20923-20930.

Schnepf, H. E., and Whiteley, H. R. (1981). Proc. Natl. Acad. Sci. USA 78, 2893-2897.

Schnepf, H. E. (1995). Curr. Opin. Biotechnol. 6(3), 305-312.

Schwartz, J. L., Potvin, L., Dean, D., and Laprade, R. (1995). Biophys. J. 68(2 Part 2), A203.

Schwartz, J.-L., Garneau, L., Savaria, D., Masson, L., Brousseau, R., and Rousseau, E. (1993). J. Membrane Biol. 132, 5362.

Schwartz, J.-L., Garneau, L., Masson, L., and Brousseau, R. (1991a). Biochim. Biophys. Acta 1065, 250-260.

Schwartz, J. M., Tabashnik, B. E., and Johnson, M. W. (1991b). Entomol. Exp. Appl. 61, 179-187.

Sekar, V., Thompson, D. V., Maroney, M. J., Bookland, R. G., and Adang, M. J. (1987). Proc. Natl. Acad. Sci. USA 84, 7036-7040.

Sen, K., Honda, G., Koyama, N., Nishida, M., Neki, A., Sakai, H., Himeno, M., and Komano, T. (1988). Agric. Biol. Chem. 52, 873-878.

Shevelev, A. B., Svarinsky, M. A., Karasin, A. I., Kogan, Y. N., Chestukhina, G. G., and Stepanov, V. M. (1993). FEBS Lett. 336, 79-82.

Shibano, Y., Yamagatcl, A., Nakamura, N., Iizukcs, T., Sugisaki, H., and Takanami, M. (1985). Gene 34, 243-251.

Shimizu, M., Oshie, K., Nakamura, K., Takada, Y., Oeda, K., and Ohkawa, H. (1988). Agric. Biol. Chem. 52, 1565-1573.

Shin, B. S., Park, S. H., Choi, S. K., Koo, B. T., Lee, S. T., and Kim, J. I. (1995). Appl. Environ. Microbiol. 61(6), 2402-2407.

Sick, A., Gaertner, F., and Wong, A. (1990). Nucleic Acids Res. 18, 1305.

Sims, S. R., and Stone, T. B. (1991). J. Invertebr. Pathol. 57, 206-210.

Smith, G. P., and Ellar, D. J. (1994). Biochem. J. 302, 611-616.

Smith, R. A., and Couche, G. A. (1991). Appl. Environ. Microbiol. 57, 311-315.

Smulevitch, S. V., Ostermcin, A. L., Shevelev, A. B., Kaluger, S. V., Karasin, A. I., Kadyrov, R. M., Zagnitko, O. P., Chestukhina, G. G., and Steponov, V. M. (1991). FEBS Lett. 293, 25-28.

Soltes-Rak, E., Kushner, D. J., Williams, D. D., and Coleman, J. R. (1993). Appl. Environ. Microbiol. 59, 2404-2410.

Srinivas, G., Murty, M. G., and Sekar, V. (1995). Microbios 81(328), 147-154. 
Steinhaus, E. A. (1951). Hilgardia 20, 359-381.

Stewart, C. N. Jr., Adang, M. J., All, J. N., Boerma, H. R., and Parrott, W. A. (1995). Plant Physiol. (Rockville) 108(Suppl. 2), 22.

Sutton, D. W., Havstad, P. K., and Kemp, J. D. (1992). Transgenic Res. 1, 228-236.

Tabashnik, B. E., Finson, N., Chilcutt, C. F., Cushing, N. L., and Johnson, M. W. (1993). J. Econ. Entomol. 86, 635-644.

Tabashnik, B. E., Finson, N., and Johnson, M. W. (1991). J. Econ. Entomol. 85, 2082-2087.

Tabashnik, B. E., Cushing, N. L., Finson, N., and Johnson, M. W. (1990). J. Econ. Entomol. 83, 1671-1676.

Tabashnik, B. E. (1990). In "Pesticide Resistance in Arthropods" (R. T. Roush and B. E. Tabashnik, eds.), pp. 153-182. Chapman \& Hall, New York.

Tabashnik, B. E. (1994). Annu. Rev. Entomol. 39, 47-79.

Tailor, R., Tippett, J., Gibb, G., Pells, S., Pike, D., Jordon, L., and Ely, S. (1992). Mol. Microbiol. 6, 1211-1217.

Thompson, C. J., Movva, N. R., Tizard, R., Carmeir, R., Davies, J. E., Lauwereys, M., and Botterman, J. (1987). EMBO J. 6, 2519-2523.

Thorne, L., Garduno, F., Thompson, T., Decker, D., Zounes, M. A., Wild, M., Walfield, A. M., and Pollock, T. J. (1986). J. Bacteriol. 166, 801-811.

Tiedje, J. M., Colwell, R. K., Grossman, Y. L., Hodson, R. E., Lenski, R. E., Mack, R. N., and Regal, P. J. (1989). Ecology 70, 298-314.

Tojo, A., and Aizawa, K. (1983). Appl. Environ. Microbiol. 45, 576-580.

Travers, R. S., Faust, R. M., and Reichelderfer, C. F., (1976). J. Invertebr. Pathol. 28, 351-356.

Tungpradubkul, S., Settasatien, C., and Panyim, S. (1988). Nucleic Acids Res. 16, 1637-1638.

Turner, J. T., Lampel, J. S., Stearman, R. S., Sundin, G. W., Gunynzki, P., and Anderson, J. J. (1991). Appl. Environ. Microbiol. 57, 3522-3528.

Udayasuriyan, V., Nakamura, A., Masaki, H., and Uozumi, T. (1995). World J. Microbiol. Biotechnol. 11(2), 163-167.

Uemura, T., Ihara, H., Wadana, A., and Himeno, M. (1992). Biosci. Biotechnol. Biochem. 56, 1976-1979.

Vadlomudi, R. K., Weber, E., Ji, I., Ji, T. H., and Bulla, L. A., Jr. (1995). J. Biol. Chem. 270, $5490-5494$.

Vadlomudi, R. K., Ji, T. H., and Bulla, L. A., Jr. (1993). J. Biol. Chem. 268, 12334-12340.

Vaeck, M., Reynaerts, A., Hofte, H., Jansens, S., DeBeuckeleer, M., Dean, C., Zabeau, M., VanMontagu, M., and Leemans, J. (1987). Nature 328, 33-37.

Van der Salm, T., Bosch, D., Honee, G., Feng, L., Munsterman, E., Bakker, P., Stiekema, W.J., and Visser, B. (1994). Plant Mol. Biol. 26, 51-59.

Van Rie, J., Jansens, S., Hohe, H., Degheele, D., and Van Mellaert, H. (1990a). Eur. J. Biochem. 186, 239-247.

Van Rie, J., Jansens, S., Hohe, H., Degheele, D., and Van Mellaert, H. (1990b). Appl. Environm. Microbiol. 56, 1378-1385.

Van Rie, J., McGaughey, W. H., Johnson, D. E., Barnett, B. D., and Van Mallaert, H. (1990c). Science 247, 72-74.

Van Tersch, M. A., Slatin, S. L., Kulesza, C. A., and English, L. H. (1994). Appl. Environ. Microbiol. 60, 3711-3717.

Visser, B., Munsterman, E., Stoker, A., and Dirkse, W. G. (1990). J. Bacteriol. 172, 6783-6788.

Waalwijk, C., Dullemans, A. M., vanWorkum, M. E. S., and Visser, B. (1985). Nucleic Acids Res. 13, 8207-8217. 
Wabiko H, and Yasuda, E. (1995). Microbiology (Reading) 141(3), 629-639.

Wabiko, H., Raymond, K. C., and Bulla, L. A., Jr. (1986). DNA 5, 305-314.

Ward, E. S., and Ellur, D. J. (1987). Nucleic Acids Res. 15, 7195.

Ward, E. S., Ellar, D. J., and Chilcott, C. N. (1988). J. Mol. Biol. 202, 527-535.

Watrud, L., Perlak, F. J., Tran, M. T., Kusano, K., Mayer, E. J., Miller-Wideman, M. A., Obukowicz, M. G., Nelson, D. R., Kreitinger, J. P., and Kaufman, R. J. (1985). In "Engineered Organisms in the Environment" (O. H. Halvorson, D. Pramer, and M. Rogul, eds). pp 40-46. American Society for Microbiology, Washington D.C.

Wetzel, R. 1988. Protein. Eng. 2:1-3.

Whalon, M.E., and McGaughey, W.H. (1993). In "Advanced Engineered Pesticides " (L. Kim, ed.) pp. 215-231. Dekker, New York.

Widner, W. R., and Whirteloy, H. R. 1989.J. Bacteriol.171, 965-974.

Williams, S., Friedrich, L., Dincher, S., Carozzi, N., and Kessman, H. (1992). Biotechnology. 10, 540-543.

Wiwat, C., Panbangred, W., Mongkolsuk, S., Pantuwatana, S., and Bhumiratana, A. (1995). Curr. Microbiol. 30(2), 69-75.

Wolfersberger, M. G. (1990). Experentia 46, 475-477.

Wolfersberger, M. G. (1989). Arch. Insect. Biochem. Phys. 12, 267-277.

Wolfersberger, M., Luethy, P., Maurer, A., Parenti, P., Sacchi, F. V., Giordana, B., and Hanozet, G. M. (1987). Comp. Biochem. Physiol. A 86, 301-308.

Wolfersberger, M. G., Chen, X., and Dean, D. H. (1995). Insect Biochem. Mol. Biol., in press.

Wong, E. Y., Hironaka, C. M., and Fischhoff, D. A. (1992). Plant Mol. Biol. 20, 81-93.

Wu, D., Cao, X. L., Bai, Y. Y., and Aronson, A. L. (1991). FEMS Microbiol. Lett. 81, 31-36.

Wu, D., and Aronson, A. I. (1992). J. Biol. Chem. 267, 2311-2317.

Wu, D., and Federici, B. A. (1995). Appl. Microbiol. Biotechnol. 42, 697-702.

Yamamoto, T., Watkinson, I. A., Kim, L., Sage, M. V., Stranon, R., Akande, N., Li, Y., Ma, D. P., and Rose, B. A. (1988). Gene 66, 107-120.

Yang, C. C., Pan, I. H., Chen, M. H., Kao, S. S., and Tsai, Y. S., (1995). Bacillus thuringiensis formulated with anti-ultraviolet agent. Patent: U.S. 5427787; Application: U.S. 153355 (931115).

Yoshisue, H., Ihara, K., Nishimoto, T., Sakai, H., and Komano, T., (1995a). Gene (Amsterdam) 154(1), 23-29.

Yoshisue, H., Ihara, K., Nishimoto, T., Sakai, H., and Komano, T. (1995b). FEMS Microbiol. Lett. 127(1-2), 65-72.

Zhang, M.-Y., and Lovgren, A. (1995). Gene (Amsterdam) 158(1), 83-86.

Zimanyi, I., Macintosh, S. C., and Wilms, B. (1995). Biophys. J. 68(2 Part 2), A388. 